\title{
Geophysical Detection and Assessment of Leveled Mounds: An Example from the Upper Mississippi Valley
}

\author{
William Green (D), Adam S. Wiewel, and Steven L. De Vore
}

\begin{abstract}
Most earthen burial mounds of eastern North America have been destroyed —or have they? We review geophysical methods for assessing whether leveled mounds retain intact deposits or features. Magnetic survey holds promise for locating and evaluating leveled mounds because it is rapid and sensitive to magnetic variations associated with anticipated features such as pits and deposits of mound fill. As a case study, we discuss our magnetic survey of the Gast Farm site (13LA12) in eastern Iowa. The survey covered 8.64 ha, encompassing loci of one previously reported mound and possible geometric earthworks as well as Middle and Late Woodland habitation areas. Interpretation of survey results incorporated quantitative differentiation of magnetic anomaly types using GIS techniques, along with standard visual inspection. We found no evidence of geometric earthworks but identified at least six leveled mounds. Displaced mound fill appears to account for the earthwork-like features. We conclude that leveled mounds are detectable and may retain subsurface integrity. Their associated features, including burials, may be identifiable even when above-ground evidence has disappeared.
\end{abstract}

Keywords: mounds, geophysical survey, magnetometry, GIS, U.S. Midwest

La mayoría de túmulos del este de Norteamérica han sido destruidos- ¿o no? Nosotros revisamos los métodos geofísicos para evaluar si los túmulos nivelados retienen depósitos o rasgos intactos. Una encuesta magnética da esperanzas de encontrar y evaluar los túmulos nivelados porque es rápida y sensitiva a las variaciones magnéticas asociadas con rasgos anticipados como hoyos y depósitos de relleno de túmulos. Como estudio de caso, hablamos sobre nuestro estudio magnético del sitio de Gast Farm (13LA12) en el este de Iowa. La encuesta abarcó 8,64 ha, cubriendo tanto como sitios de un túmulo previamente reportado y posibles movimientos de tierra geométricos, así como áreas de habitación de los períodos Middle y Late Woodland. La interpretación de los resultados de la encuesta incorporó la diferenciación cuantitativa de los tipos de anomalías magnéticas utilizando técnicas del sistema de información geográfica (SIG), junto con la inspección visual estándar. No encontramos ninguna evidencia de movimientos de tierra geométricos, pero identificamos al menos seis túmulos nivelados. El relleno del túmulo desplazado parece explicar las características de movimiento de tierras. Concluimos que los túmulos nivelados son detectables y pueden retener la integridad del subsuperficie. Sus características asociadas, incluidos los entierros, pueden ser identificables incluso cuando la evidencia sobre la tierra ha desaparecido.

Palabras clave: túmulos, encuesto geofisico, magnetometria, SIG, Medio Oeste de EE. UU.

\section{Native American Mounds}

$\mathrm{T}$ The practice of mound building was widespread throughout eastern North America, with upward of 100,000 mounds documented. Early observers of these readily visible physical remnants of ancient cultures designated the continent's original inhabitants as the Mound Builders (Barnhart 2015; Mallam 1976;

William Green (greenb@ beloit.edu, corresponding author) $\mathbf{O}$ Office of the State Archaeologist, University of Iowa, 700 Clinton St. Building, Iowa City, IA 52242, USA; Logan Museum of Anthropology, Beloit College, 700 College St., Beloit, WI 53511, USA

Adam S. Wiewel and Steven L. De Vore - Midwest Archeological Center, National Park Service, 100 Centennial Mall North, Room 474, Lincoln, NE 68508, USA

American Antiquity 86(2), 2021, pp. 305-326

Copyright (C) The Author(s), 2021. Published by Cambridge University Press on behalf of the Society for American Archaeology. This is an Open Access article, distributed under the terms of the Creative Commons Attribution licence (http://creativecommons.org/licenses/by/4.0/), which permits unrestricted re-use, distribution, and reproduction in any medium, provided the original work is properly cited.

doi:10.1017/aaq.2020.103 
Silverberg 1968; Timmerman 2020). Mound building so epitomized Native societies in the archaeological imagination that scholars referred to the most recent cultural stages or periods of eastern North America as Burial Mound I and II and Temple Mound I and II (Ford and Willey 1941; Willey 1966). We know now that Native Americans began building mounds as early as $3500 \mathrm{BC}$ and that most mounds date to the Woodland and Late Prehistoric periods, approximately 500 BC-AD 1400 (Buikstra 1988; Gibson 2019; Milner 2004, 2009).

Native American mounds in eastern North America are mainly earthen structures. Some incorporate stone features or comprise mostly shell, but most mounds in the Mississippi River drainage and Great Lakes region are formed principally of redeposited soil or other unconsolidated mineral sediment. In this article, the term "mounds" will denote conical (circular, dome-shaped) structures as well as those with oval, linear, effigy, and truncated-pyramidal (platform) forms. We refer to other types of earthen structures-such as geometric or ditched enclosures-as "earthworks," even though mounds, broadly speaking, are earthworks.

This article addresses detection of leveled mounds and assessment of their integrity using geophysical survey methods. Mounds and earthworks are highly susceptible to damage by agricultural practices. Land-leveling is an obvious cause, but normal farming methods such as plowing and cultivation also reduce their aboveground visibility (Limp 1987; Schurr 1999). Damage by leveling and plowing does not only result from mechanized agriculture. Mounds also were flattened by horse-drawn slips and similar low-tech methods. Surface indications of thousands of mounds disappeared in agricultural fields in the nineteenth and twentieth centuries (Petersen 1984; Snead 2018:243-244; Whittaker 2020).

Most mounds are burial mounds. Nearly all carefully excavated conical, linear, and effigy mounds have produced human remains (Arzigian and Stevenson 2003; Rosebrough 2011). Platform mounds, which are generally substructures for buildings, also may contain burials (Fairbanks 1956; Rowe 1958). As burial site protection has gained importance across North America, it is becoming vital to locate and preserve as many mounds as possible. It is also important to determine whether leveled or otherwise disturbed mounds retain any integrity and, potentially, human remains. A flattened mound is not necessarily a destroyed mound. Throughout eastern North America, interments were often placed in subterranean or "subfloor" tombs or pits over which the mound itself was built (Benn 2009; Charles et al. 2004; Van Nest 2006; Van Nest et al. 2001). To prepare a clean surface, topsoil often was removed from the area to be covered by a mound. Occasionally, a wooden structure was built and dismantled prior to construction of the mound, with posts extending into subsoil. Mounds often were built in stages composed of distinct layers of fill of differing color and texture. Because subfloor pits, prepared surfaces, substructures of buildings, and basal mound building stages often occur at depths below current plow zones, these features may be preserved when no surface relief exists. Our challenge is to find effective and efficient ways to detect such features.

\section{Detecting Leveled Mounds}

Indications of leveled mounds sometimes appear in aerial photography. Images made as early as the 1920s show mounds whose exposed fill contrasts with surrounding topsoil (Fowler 1977; Giardino and Haley 2006). Recent aerial and space-based imagery also permits detection of plowed and leveled mounds in bare-earth settings or when differential vegetation growth allows identification of cultural features, such as through infrared imaging or thermography (Giardino and Haley 2006). Ground cover frequently obscures visibility, however, and aerial-based remote sensing is often not sufficiently sensitive to detect small mounds or those with subtle soil signatures. Archaeologists can use lidar to detect damaged mounds, but lidar is of limited use in identifying earthworks less than $10 \mathrm{~cm}$ higher than the surrounding surface (Whittaker 2020; Whittaker and Riley 2012), so it can be difficult-if not impossible-to differentiate plowed-down mounds from undulations caused by plowing.

Here, we consider ground-based methods for detecting leveled mounds and associated features. Several geophysical survey methods 
are effective in locating subsurface anomalies (Clark 1990; Horsley 2015; McKinnon and Haley, ed. 2017). Magnetometry is a useful method of assessing features located within 1$2 \mathrm{~m}$ of the surface because surveys can be undertaken quickly, returning precise and accurate results (Kvamme 2006a). Magnetic surveys are suitable for identifying archaeological features because several natural processes lead to magnetic variations in the ground that are exacerbated by human activities (Aspinall et al. 2009; Clark 1990; Kvamme 2006a). For instance, intense firing-as occurs when a hearth is burned, an earth oven is used to cook, or a structure is incinerated-produces magnetic contrasts, or anomalies, with surrounding deposits as the heated features undergo thermoremanent magnetization. Other features are formed from materials that differ in their magnetic susceptibilities from adjacent soil and sediments. The magnetization of such features is induced by the Earth's magnetic field rather than remanent. For example, pits and ditches often exhibit moderately high magnetic signatures. When their use ends, they are filled, either intentionally or through erosion, with magnetically enriched soils and refuse containing fired objects and organic waste. Magnetometers do not discriminate induced and remanent forms of magnetism. Instead, they measure their sum.

Magnetometry is revolutionizing our understanding of archaeological sites and landscapes. After decades of application in Great Britain, magnetic surveys in eastern North America have identified ancient dwellings, hearths, storage pits, walls, and other features preserved beneath agricultural fields. Numerous examples can be cited. In western Illinois and eastern Iowa alone, recent studies include Barrier and Horsley (2014), De Vore (2014), Friberg (2018), Horsley and colleagues (2015), and Wilson and Pike (2015). This work suggests that subsurface features associated with leveled mounds should also be detectable.

Mound studies employing geophysical methods in eastern North America mainly address off-mound features as well as the internal features and structure of extant (although often damaged) mounds rather than leveled mounds (e.g., Betts and Stay 2017; Bigman and Seinfeld 2017; Britt et al. 2002; Burks and Locke-Rogers 2015; Dalan 2006; Hammerstedt et al. 2017; Hargrave et al. 2007; Kassabaum et al. 2014; Lynott 1997, 2015; McKinnon and Haley 2017; Messerole 2017; Zimmer-Dauphinee 2017). Studies of Havana Hopewell Middle Woodland mound sites in the Illinois and Mississippi River valleys are no exception, employing geophysical survey primarily at extant rather than leveled earthworks. Magnetometry and other methods have discerned internal features of mounds at four sites in the lower Illinois River valley (Herrmann et al. 2014; King et al. 2017; McKinnon et al. 2016). Likewise, McCullough's (2018) geophysical survey of the extant Nadine Mound Group (11HE69) on the Mississippi River bluffs in western Illinois detected central (presumably mortuary) features and possible accretional mound stages. On a low terrace in the Mississippi River valley in northeast Iowa, Whittaker and Storey's (2008) groundpenetrating radar study of 101 extant Middle and Late Woodland mounds at the Sny Magill Mound Group (13CT18) identified internal anomalies in most mounds.

Geophysical survey has detected remnants of plowed mounds at several Woodland and Late Prehistoric sites. At the Goodall site (12LE9), a Middle Woodland mound group in northwest Indiana (Mangold and Schurr 2006; Quimby 1941), plowing of its sandy soil led to nearobliteration of most mounds. Magnetic and resistivity survey of several $10-20 \mathrm{~cm}$ elevations, followed by test excavations, confirmed that they were mound remnants. The most distinct signature is a circular, $17 \mathrm{~m}$ diameter ring of low magnetism surrounding a small, central, high-magnetic anomaly (Schurr 1999: Figure 21). At the Hollywood Mounds in Mississippi, magnetic survey identified remnants of Mississippian houses that once sat atop small platform mounds that had been reported in the early twentieth century, many of which were subsequently plowed down to near invisibility (Haley 2014).

Surveys of mounds with no remaining surface expression are rare. De Vore's (2009) geophysical survey at Effigy Mounds National 
Monument in northeast Iowa identified likely outlines of several previously mapped mounds (13AM82) whose surface expressions had disappeared, as well as several unmapped mounds. At the nearby Turkey River Mound Group (13CT10) on a Mississippi River bluff top, geophysical survey detected several previously mapped but plowed-down mounds: "Despite years of cultivation at the site, the gradiometry survey results show that a portion of the mounds remains well intact at an undisturbed level below the plow zone" (Mathys 1997:28). At Cahokia, Illinois, conductivity survey rediscovered leveled mounds and other features (Dalan 1991). Conductivity survey at the Deer Creek site (34KA3) in Oklahoma also detected possible signatures of previously recorded leveled mounds, although the mounds may have been midden mounds rather than burial mounds (Bevan 1983:49). At the latter two sites, surveys consisted of single transects and profiles rather than areal coverage showing possible mound plans or internal features. Skousen (2019) sought traces of plowed-down Mississippian platform mounds through magnetic survey at the Otter Pond site (11LW9) in southeastern Illinois. Wall-trench domestic structures showed up well, but the leveled mounds were not evident.

Regarding earthworks, resurveys of Ohio Valley Hopewell and Adena enclosures are refining legacy maps, finding new features, and recording new sites in previously unsurveyed tracts. Most of the newly detected earthworks are geometric enclosures whose surface evidence was plowed away but whose highly magnetic infilled ditches contrast well with surrounding subsoil (Burks and Cook 2011; Henry et al. 2019; Horsley et al. 2014; Wright 2014). Few of these leveled earthworks appear in aerial imagery, and nearly none in lidar coverage. Magnetic surveys also have identified infilled ditch enclosures at Plains sites (Drass et al. 2019; Kvamme 2007a).

Magnetometry survey located traces of a plowed-down octagonal enclosure at the McKinney site (13LA1), adjacent to the Havana Hopewell Toolesboro Mounds (13LA29) in southeast Iowa (De Vore 2015). The embankment walls had been more than $2 \mathrm{~m}$ high, but they were flattened by farming and are now invisible from the air and barely discernible using lidar (Newhall 1841; Riley and Tiffany 2014). The embankment apparently lacked the distinctive ditches that facilitate detection of other plowed earthworks. The magnetic survey, however, identified distinctive concave outlines as originally mapped for each segment of the enclosure-a detail that does not appear in the lidar study.

\section{Case Study: Gast Farm}

\section{Gast Farm Site Background}

Building on the foregoing studies, we assess the effectiveness of magnetometry for detecting leveled mounds and associated features by summarizing recent work at the Gast Farm site (13LA12) in southeast Iowa (Green 2018; Wiewel and De Vore 2018). Gast Farm is a 12 ha site situated atop and within an alluvial fan in the Mississippi River valley (Figure 1). The surface soils (loams with A-Bt and A-Bw horizons) have been relatively stable for about the past 2,300 years, except for cultivation of the upper approximately $30 \mathrm{~cm}$ (Bettis et al. 1992; Brown 1988). Controlled surface collections and excavations from 1990 through 1994 showed that Middle Woodland material and features (Havana Hopewell variant, ca. 50 BC-AD 250) occur in the eastern part of the site, and a Late Woodland village (Weaver variant, ca. AD 350-500) occupies the western part. Early Woodland material (Black Sand variant, ca. 450-100 BC) clusters in the central part and occurs in low-density scatters throughout the site (Benn and Green 2000; Bettis et al. 1992; Dunne 2002; Green and Wallace 1991; Johnson 2002; Neverett 2001; Weitzel and Green 1994).

A large mound existed in the center of the site. In the 1950s, landowner Dan Gast tried to interest archaeologists in the mound, but as a result of mutual misunderstandings, Gast leveled the mound. During earthmoving, he recovered typical Havana Hopewell ceremonial objects: copper axes, platform pipes, and sheet mica (Office of the State Archaeologist [OSA] accession 7210). The mound had been well known locally, with reports suggesting it 


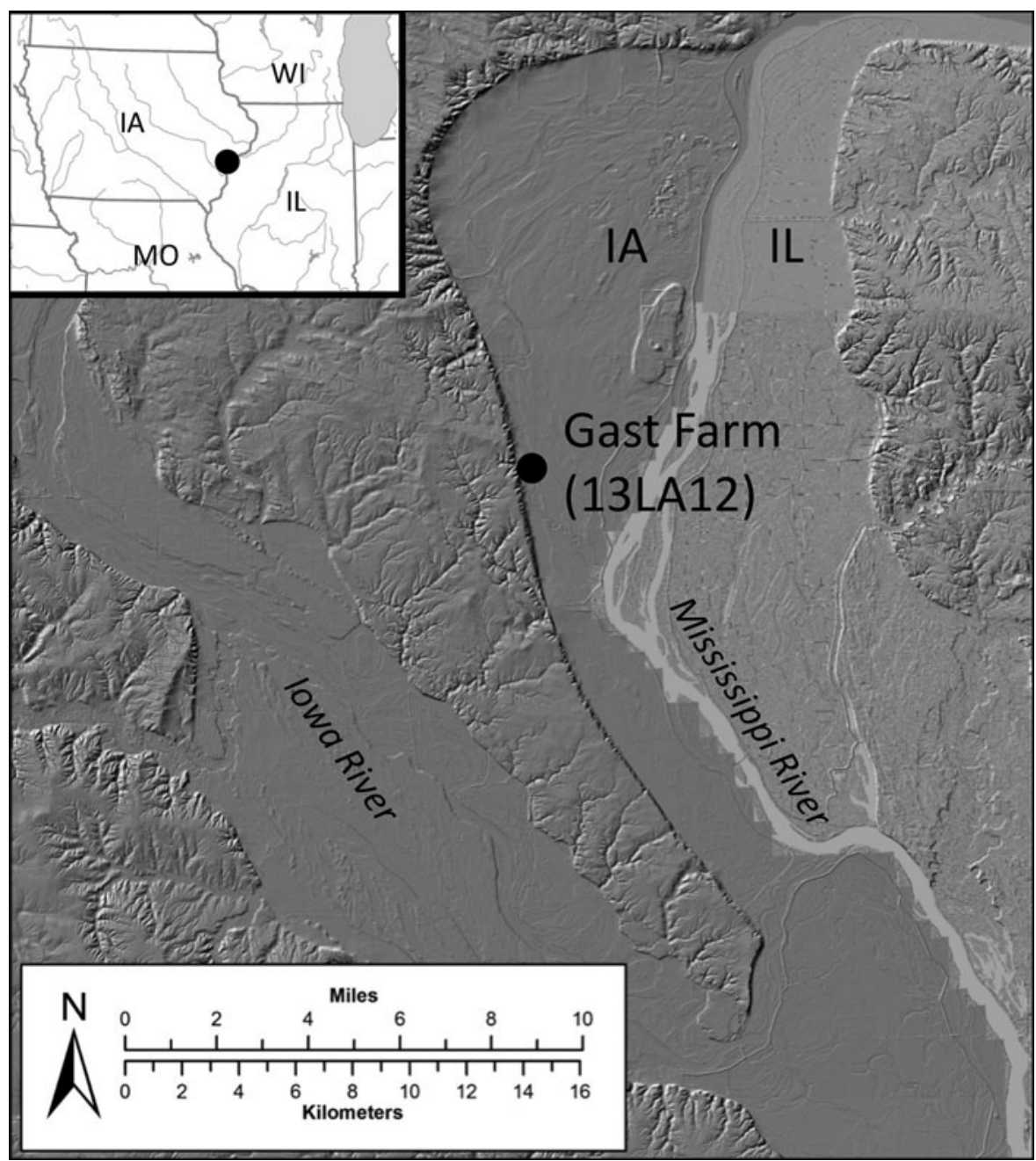

Figure 1. Gast Farm location map. Base map: Iowa and Illinois statewide lidar coverage (Illinois State Geological Survey 2020; Iowa Department of Natural Resources 2020).

measured approximately $30 \mathrm{~m}$ in diameter and up to $3 \mathrm{~m}$ in height. We have found no photographs of the mound. Its former location appears on a sketch map made around 1970 that includes the note "mound is gone can still see the site" (Royster ca. 1970), indicating that the locus of the leveled mound exhibited distinctive surface soil characteristics.

Aerial imagery (Figure 2; Supplemental Figure 1; Supplemental Table 1) and surface observations show that the mound's location is marked by light-colored soil that contrasts with the surrounding surface. Some photos also show dark-colored, organically enriched soil indicating the Middle Woodland and Late Woodland occupation areas. Although the light soil indicates the mound's location before and after it was leveled, its outline and dimensions cannot be discerned in any photo (see Supplemental Text 1). Low-altitude oblique color and color infrared air photos show the light-colored flattened mound locus as well as several broad, linear bands of light-colored soil (Figure 3). Figure 4 is an orthophoto derived from rectifying and georeferencing the oblique photos (see Supplemental Text 1). The latter image helps us to locate the mound area and linear bands but does not permit 


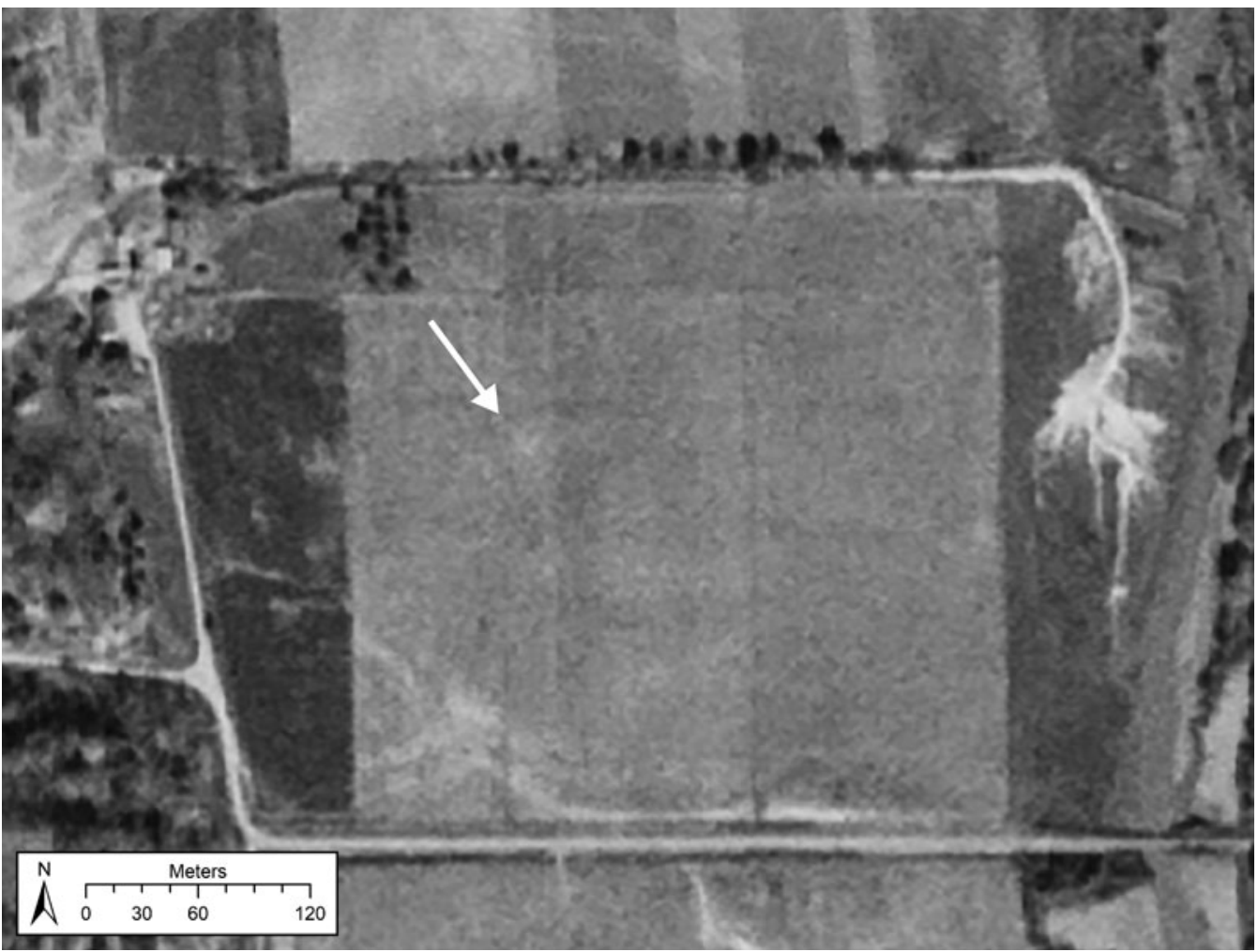

Figure 2. Vertical panchromatic air photo of Gast Farm, October 1949. Mound location indicated by light-colored soil (arrow). (Source: Photo A000700080454, Army Map Service; U.S. Geological Survey 2020).

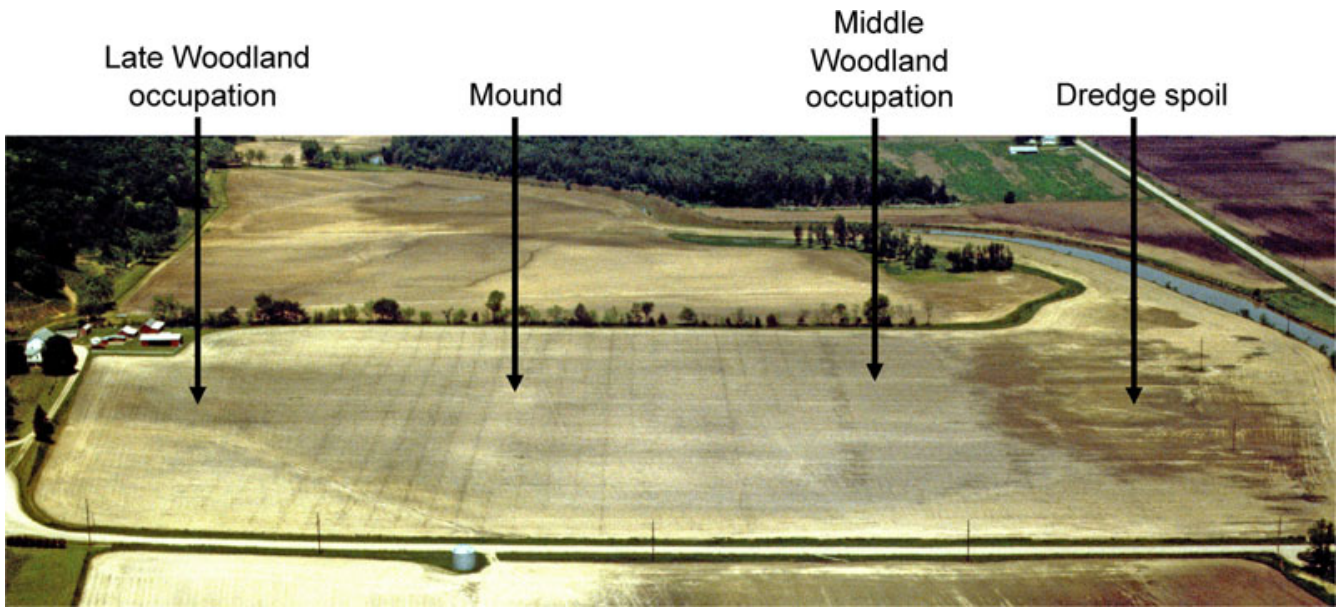

Figure 3. Oblique Kodachrome air photo of Gast Farm. View to north. Closely spaced north-south lines are pathways $10 \mathrm{~m}$ apart made during the controlled surface collection. Light-colored bands were thought to be possible earthworks. (Photo taken by William Green, May 1990.)

determination of mound outline or dimensions. We initially interpreted the linear bands as possible remnants of geometric earthworks
(Whittaker and Green 2010). This possibility contributed to the research design for the geophysical survey. 


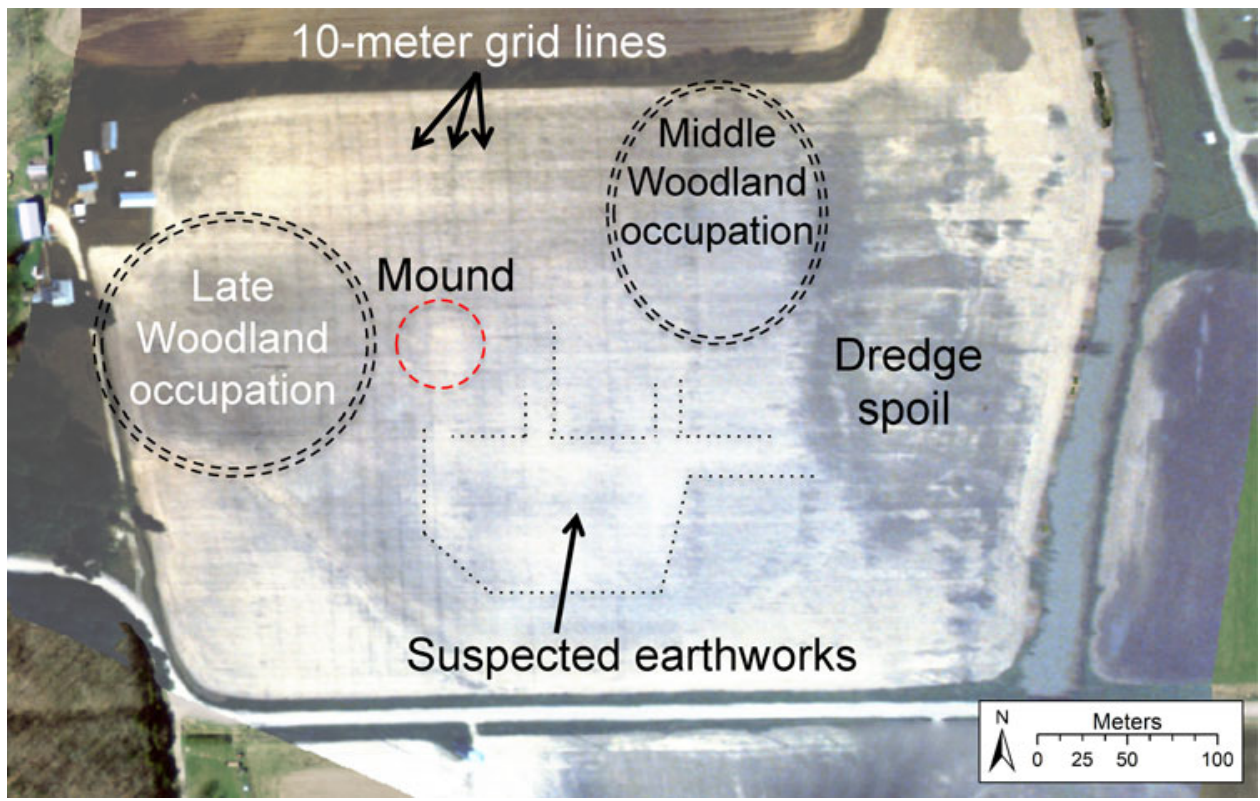

Figure 4. Orthorectified air photo of Gast Farm from digital scans of images from the 1990 oblique photo series. (Image created by Adam Barnes, University of Arkansas, using Agisoft PhotoScan. Used with permission.)

\section{Magnetometry Survey}

To ascertain whether the mound locus retained subsurface integrity and to compare it to other Havana Hopewell mounds, we sought details about mound form and associated features. Research questions also included identifying features associated with the habitation areas and the possible earthwork. Consequently, the goal of the Gast Farm geophysical survey was to document subsurface features that would assist in determining (1) the nature and extent of the mound and possible earthwork complex, and (2) the layouts of the Woodland residential areas. During a two-week period in November 2016, we surveyed $21620 \times 20 \mathrm{~m}$ grids, totaling an area of $86,400 \mathrm{~m}^{2}$. The survey excluded only a small portion of the Late Woodland settlement and the southernmost part of the possible earthwork. Ideally, we would have conducted the geophysical survey prior to the 1990-1994 fieldwork, but funding limitations precluded such work.

Wide-area geophysical surveys can yield comprehensive views of site content, feature distribution and site organization, and spatial relationships (Kvamme 2003). Multi-instrument investigations are useful because different devices provide unique and complementary information (Kvamme 2006b, 2007b; Kvamme, Ernenwein, et al. 2006; Kvamme, Johnson, and Haley 2006). The investigation at Gast Farm, however, was limited to a magnetometry survey because of (1) the method's sensitivity to magnetic variations resulting from specific anticipated features such as hearths, earth ovens, and pits, and (2) its successful use at similar and nearby sites (De Vore 2009, 2014, 2015). The method's rapid measurement rate, even at a high sampling density, was crucial given the broad scope of the project. Another advantage of magnetometry is that it is repeatable unless magnetic anomaly sources are removed. As a passive method that only measures magnetic field strength, it is not affected by changes in soil moisture as is the case with active systems, including earth resistance, ground-penetrating radar, and electromagnetic induction. These other methods could produce equally impressive and different results, but comparable surveys with these techniques would require greater cost and time investment, neither of which were possible. Furthermore, magnetometry survey 
was ideal given the field's uneven ground surface and abundant corn stubble. This is because unlike the other instruments, magnetometers are carried above the ground and vegetation. Prior to any future excavations based on the results of our investigation, however, it would be prudent to perform targeted surveys with one or more of these instruments. Such surveys would yield additional insight about the construction and use of the features revealed by magnetometry. For background on magnetism and magnetic survey in archaeology, and for details about the survey of the habitation areas at Gast Farm, see Wiewel and De Vore (2018). Here, we present information related to the mound and earthwork investigation.

We used two Bartington Grad601-2 fluxgate magnetic gradiometers, a magnetometer configuration with vertically separated sensors, simultaneously during the survey. With the range set to $100 \mathrm{nT}$, the instrument is capable of measuring magnetism with an effective resolution of 0.03 nT (Bartington Instruments 2020). Whether a feature can be detected with the Grad601-2 (or any magnetometer) depends on several factors, among them its size, burial depth, and magnetic susceptibility contrast with surrounding deposits (Aspinall et al. 2009; Clark 1990; Kvamme 2006a). Given the instrument's $1 \mathrm{~m}$ sensor separation, it is sufficiently sensitive to detect features such as hearths, earth ovens, and pits to burial depths of about $1.5 \mathrm{~m}$.

The raw field data can be understood as the sum of multiple components, including internal sensor noise; operator induced defects; anomalies related to erosional channels, plow marks, and ferrous metal; and archaeologically significant anomalies that represent fired features, pits, and more. Arriving at an archaeological interpretation of the magnetic data involves a processing workflow designed to minimize contributions of the nonarchaeological components and enhance the visual prominence of features. To achieve this result, we applied several functions using TerraSurveyor, a computer application designed by DW Consulting for archaeological geophysics. These toolsincluding despike, destripe, and destagger processes-are standard for magnetic instruments. Each function is described in greater detail by
Kvamme (2006c). In general, we applied them to the $20 \times 20 \mathrm{~m}$ grids as necessary to reduce noise caused by nonarchaeological sources (e.g., modern ferrous debris) and instrument or operator errors. We subsequently interpolated the data to produce a raster with uniform resolution (i.e., the survey sampling density of $0.125 \times 0.5 \mathrm{~m}$ was interpolated to $0.125 \times$ $0.125 \mathrm{~m}$ ), which provides a more continuous and visually appealing result. A low-pass filter was applied to smooth the raster dataset and further reduce noise.

Next, we used Esri ArcGIS to georeference the processed magnetic dataset to the survey grid, the coordinates of which were measured with differentially corrected GPS. Registering the raster dataset in this way facilitated visual comparison of the survey results with the remote sensing datasets mentioned previously and the controlled surface collection data, an approach that aided interpretation of the magnetic data. GIS methods discussed below were used to identify and discriminate anomalies with different characteristics across the surveyed area. Vector shapefiles were created to distinguish each anomaly type, which helped us better understand the distribution of archaeological features across the site, particularly those clustered near the habitation areas and the reported mound. (See Supplemental Text 1 for additional details regarding data collection and processing.)

\section{Results}

The magnetic findings at Gast Farm indicate hundreds of anomalies of likely archaeological significance, such as midden-filled pits and fired features such as hearths and earth ovens (Figure 5). Importantly, the results clarify the layouts of the Middle Woodland and Late Woodland settlements in the eastern and western parts of the site, particularly their roughly circular forms and the presence of central plazas at both locations. The results also indicate a paucity of apparent habitation-related features in the central part of the site (Green 2018; Wiewel and De Vore 2018). Regarding the focus of this article, the magnetic data detected no trace of geometric earthworks but show that several mounds, rather than just one, were present near the center of the 


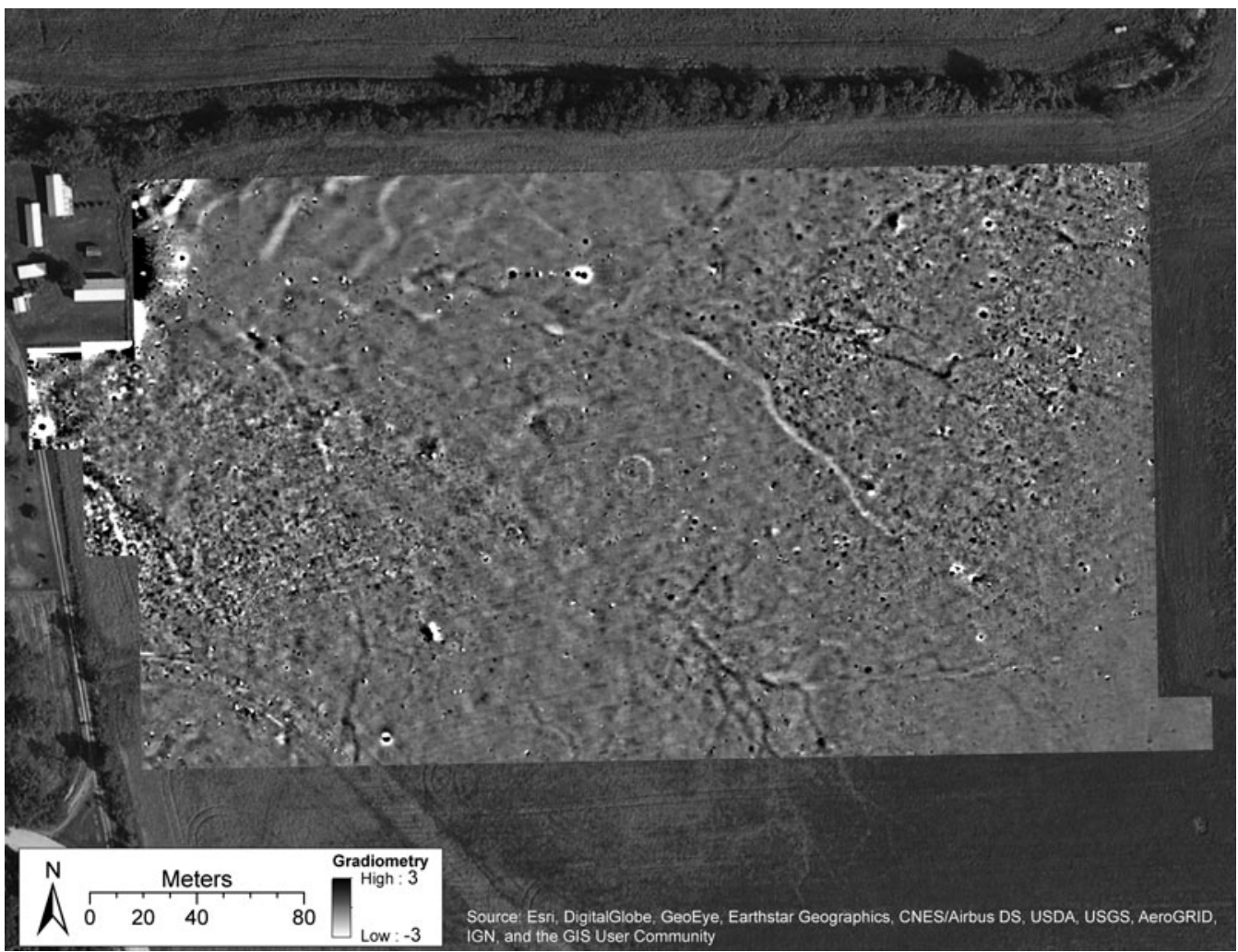

Figure 5. Results of gradiometry survey at Gast Farm. (Air photo source: Esri, DigitalGlobe, GeoEye, Earthstar Geographics, CNES/Airbus DS, USDA, USGS, AeroGRID, IGN, and the GIS User Community.)

site. The data also provide information regarding mound-related features and permit estimation of the mounds' original diameters, heights, and volumes, which allow insight into the origin of the earthwork-like surface discolorations.

\section{Magnetic Anomaly Identification}

Anomaly interpretation relies on pattern recognition and familiarity with the suite of features one may encounter at a given archaeological site as well as awareness of magnetic theory and consideration of the likely magnetic properties of each feature type (Kvamme 2006c, 2008). Anomalies are generally identified manually based on visual inspection, which is a tedious, time-consuming, and inconsistent process. As the scale of remote sensing investigations has increased, semiautomated and automated approaches to feature and site detection have been developed for aerial and satellite imagery (De Laet et al. 2007; Lasaponara et al. 2016; Trier et al. 2009), airborne lidar data (Davis et al. 2019; Schneider et al. 2015; Trier and Pilø 2012; Trier et al. 2015, 2019; Verhagen and Drăguţ 2012), and groundbased geophysical data (Panagiotakis et al. 2011; Pasolli et al. 2009; Verdonck 2016). Despite potential benefits, use of such methods for archaeological applications remains infrequent (Bennett et al. 2014; Opitz and Herrmann 2018). Although not automated, we used GIS techniques to quantitatively differentiate magnetic anomaly types, an approach that adds a level of objectivity and consistency while maintaining the sensitivity and flexibility of a standard visual inspection.

Among the magnetic anomalies are hundreds with dipolar forms, or adjacent high-magnitude positive and negative poles (Figure 5). Such anomalies are characteristic of near-surface ferrous debris. Although the densest cluster occurs near the extant farm residence, dipolar anomalies are dispersed across the field-a pattern 
consistent with the field's agricultural use for many decades. To identify these anomalies, separate layers with threshold values above $2.5 \mathrm{nT}$ and below $-2.5 \mathrm{nT}$ were created by reclassifying the magnetic dataset. Although the range between these threshold values includes some archaeological features and other anomaly sources, we found them best for discriminating background noise (i.e., sensor noise, operator error, and most soil-related anomalies). Anomalies that exceed these threshold levels are more readily explainable as fired features and pits as well as anomalies caused by eroded topsoil and ferrous metal. After the threshold layers were created, a $0.25 \mathrm{~m}$ buffer was applied to both the positive and negative vector shapefiles so that the adjacent poles of most dipolar anomalies would overlap. A Boolean AND operator was then used to detect their overlap. Still, some dipolar anomalies with weakly magnetic negative poles were only identified by reviewing the magnetic data visually. A smaller number of dipolar anomalies also appeared to indicate fired features. Each exhibits a circular positive pole about $0.5-3.0 \mathrm{~m}$ in diameter and a magnitude approaching $20 \mathrm{nT}$, with a diffuse, negative pole on the north side. Vector polygons associated with closely spaced positive and negative anomalies were subsequently merged to create an interpretive map of dipolar anomalies or metal debris.

Although this process is straightforward, differentiating positive anomalies of archaeological significance is more difficult. Whether they are caused by archaeological, natural, or other sources, the positive anomalies that result appear much the same. They generally look "monopolar" in form, but they too are dipolar like those described previously. However, because of the Earth's magnetic field inclination, which is nearly vertical at our latitude, the negative poles are located farther from the gradiometer and often go undetected. To distinguish likely archaeological features from other sources, we used some additional image processing and GIS techniques.

For visualization, we replaced the most robust magnetic measurements-dipolar anomalieswith the data mean because they obscure weaker but more important anomalies. To achieve this result, polygon features representing dipolar anomalies were converted to a raster and a reclassify function was used to convert their extreme values to the average of the magnetic dataset $(\bar{x}=-0.04)$. A cell-by-cell comparison of the resulting raster and the complete magnetic dataset was then performed with a logical OVER operator. The output of the operation consists of a raster similar to the initial magnetic dataset, although extreme magnetic values associated with dipolar anomalies have been replaced by the mean, yielding a clearer view of more relevant anomalies (Figure 6).

Plow marks are another source of noise we addressed using image processing algorithms. The diagonal southwest-northeast scars derive from periodic chisel-plowing at an approximately $15^{\circ}$ angle to the planting rows. Because the plow marks are regularly oriented and spaced, a fast Fourier transform can isolate and remove the frequency associated with them. In this case, the plow marks are too subtle to be identified in the complete dataset. Visualization of important archaeological anomalies improves, however, when limiting this processing step to smaller areas where the marks are especially prominent (Figure 7).

Finally, we used a reclassify function to create a separate layer with a threshold value of 2.5 nT to illustrate positive anomalies characteristic of archaeological features such as earth ovens, hearths, and pits. In this instance, however, dipolar anomalies and anomalies associated with erosional channels, visible in both the magnetic results and aerial photographs, were omitted. At the same time, anomalies representing likely fired features that in fact appear dipolar in form were included among the vector polygons interpreted as features. This quantitative approach to interpretation undoubtedly misses some weakly magnetic archaeological features, although it was sufficiently accurate to detect the loci and form of the Middle and Late Woodland occupations, which were documented independently by controlled surface collections. Additionally, with this comprehensive interpretation, we were able to focus our attention to other areas of the site and visually identify subtle magnetic differences related to mounds. 

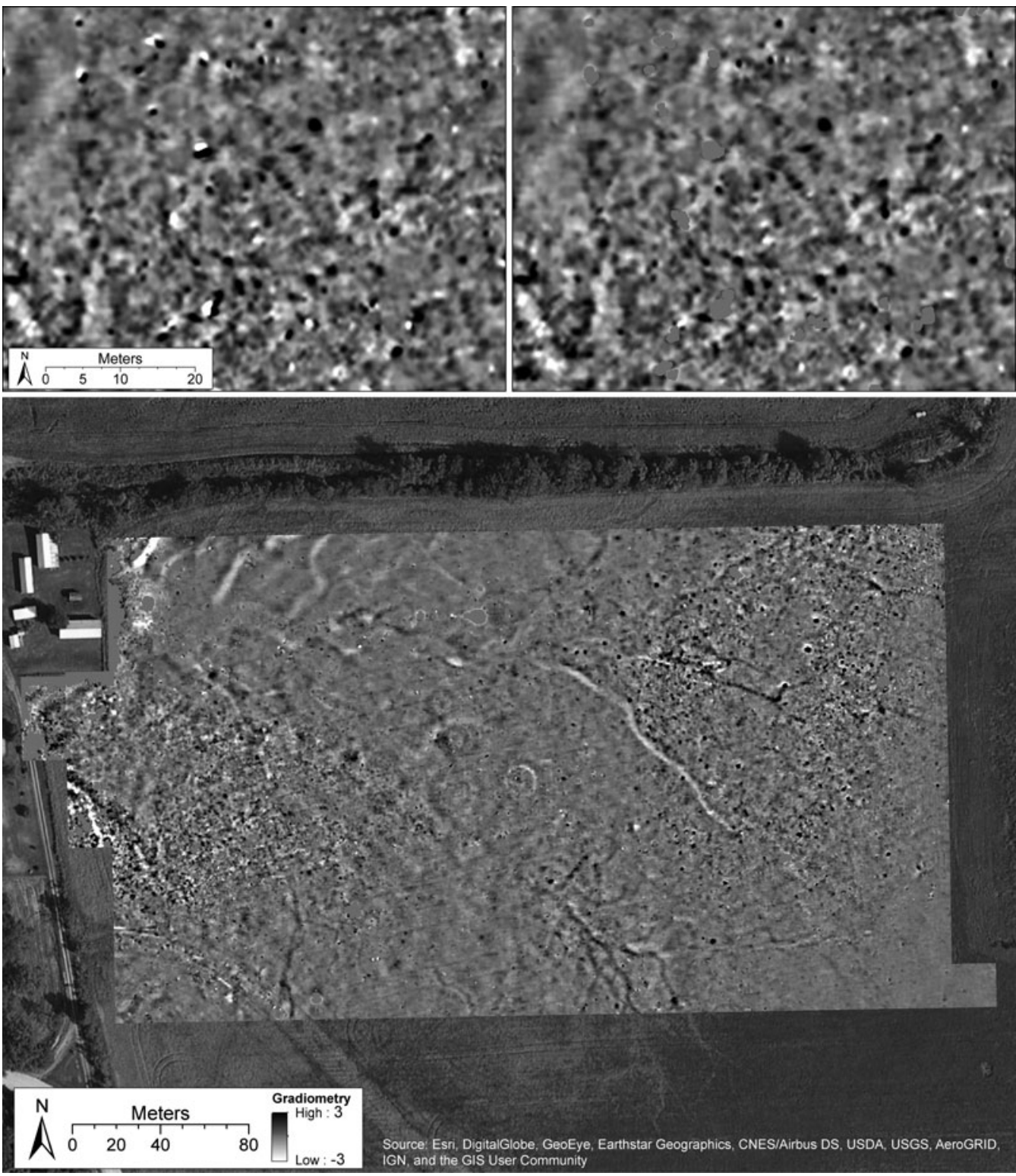

Figure 6. Close-up view of the magnetic survey results (upper left) and the same image after dipolar anomalies have been replaced with the data mean (upper right). Compare the complete magnetic results (bottom) with Figure 5 to better understand the significance of this procedure. (Air photo source: Esri, DigitalGlobe, GeoEye, Earthstar Geographics, CNES/Airbus DS, USDA, USGS, AeroGRID, IGN, and the GIS User Community.)

\section{Earthwork}

Although light-colored bands of soil visible in aerial photographs suggested the presence of a potential geometric earthwork (Whittaker and Green 2010), the magnetic data evince no hint of an earthwork (Figure 6). Although cultivation activities would have likely disturbed the supposed earthwork in recent decades, it seems unreasonable to suggest that all traces of a feature of such extent would be removed. Complete obliteration of an earthwork's magnetic signature is especially unlikely in view of the magnetic identification of the ploweddown earthwork at the McKinney/Toolesboro 

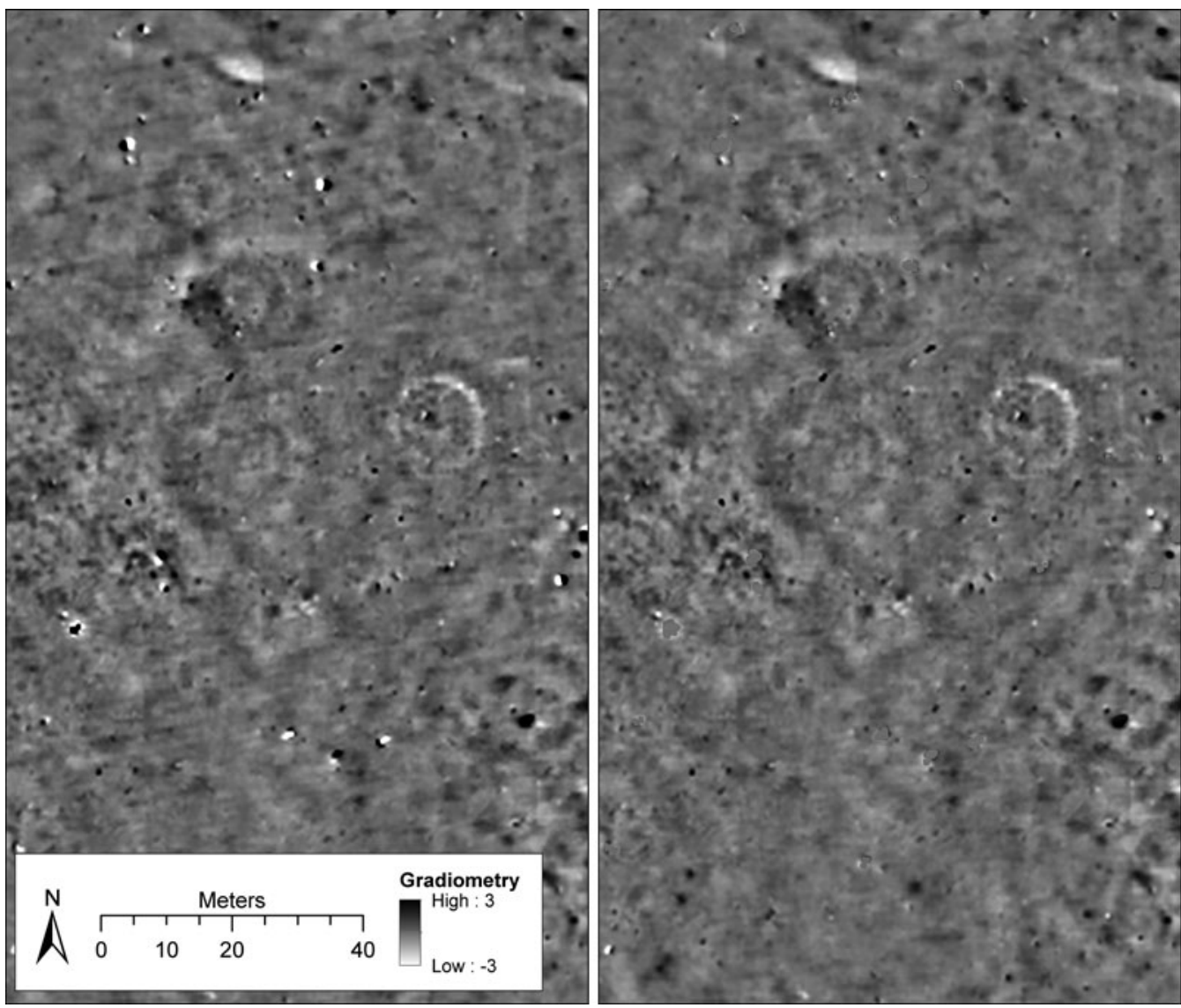

Figure 7. Example of magnetic survey results before (left) and after (right) replacing dipolar anomalies with the data mean and reducing plow marks using Fourier methods.

complex $17 \mathrm{~km}$ south of Gast Farm (De Vore 2015).

\section{Mounds}

An unexpected result of the survey was evidence for not one but several mounds, indicated by concentric rings of positive and negative magnetism (Figure 8). Elements of mound construction and use remain apparent despite decades of cultivation. An alternating pattern of positive and negative magnetism, characterizing most of the mounds, relates to their construction using sediments of varying magnetism-fills or strata of magnetically enriched organic sediment layered or interdigitating with fills or strata of low magnetic sediment (e.g., subsoil). Moreover, the signatures indicate that mound floors or basal fill layers remain intact below the plow zone, as does a central feature-presumably a crypt—in each mound. Although some magnetic signatures near the mounds represent plow-zone anomalies (e.g., subtle diagonal plow marks [Figure 7]), the clear patterning of positive and negative magnetism indicates that subsurface elements of the mounds retain their integrity.

Figure 9 shows how discrete fill zones and a subfloor burial pit can retain diagnostic magnetic properties and be detectable after a mound is leveled. Although architectural variation exists, Havana Hopewell mounds often feature a characteristic alternation of organic and less organic fill layers that overlie a burial chamber and, occasionally, a prepared basal surface (e.g., Charles et al. 1988; Herold 1971; Walker 1952). Deposits overlying the central crypt might represent primary mounds, ramps, capping episodes, sod 

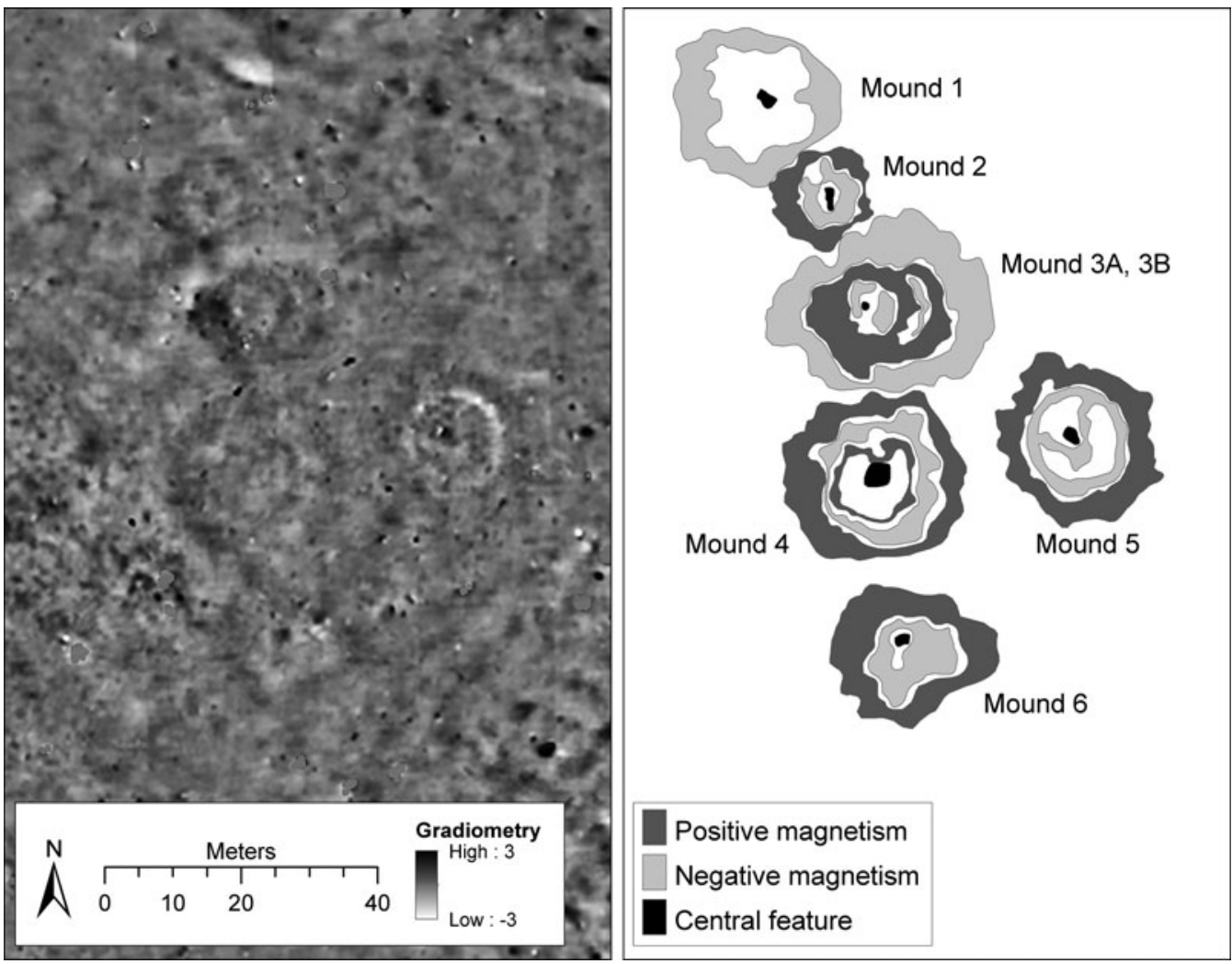

Figure 8. Magnetic gradiometry results (left) and interpretations (right) of the Gast Farm mound group.

blocks, or other types of fill or features, but all are allogenic (obtained off-site), derive from different sources (Van Nest 2006; Van Nest et al. 2001), and have different magnetic properties.

The mound group at Gast Farm consists of at least six mounds. The most conspicuous mound (Mound 5) is represented by a ring of negative magnetism approximately $15 \mathrm{~m}$ in diameter (Figure 9, bottom). This anomaly is encircled by a subtle halo of weakly positive magnetism with a diameter of about $22 \mathrm{~m}$. A positive anomaly near the center of the mound probably signifies a burial chamber.

The largest circular anomaly (Mound 4, ca. 27 $\mathrm{m}$ in diameter) corresponds to the locus of the light-colored surface soil that apparently represents the base of the large mound leveled in the 1950s (Figures 2 and 8). Mound 4 is the closest in diameter to that mound, as reported by early observers. As with Mound 5, Mound 4 also exhibits concentric rings of higher and lower magnetism and a possible central crypt.
Mounds 1, 2, 3, and 6 are also roughly circular in plan, and they contain central features (Figure 8). The perimeter of Mound 1 is marked by a ring of negative magnetism. Mound 2 contains the clearest evidence of a central burial chamber, indicated by a positive anomaly nearly $3 \mathrm{~m}$ in length and about $1.5 \mathrm{~m}$ wide. Mound 3 differs in form and may represent an elongated or biconical mound structure as at the Kamp Mound Group (11C12) in Illinois (McKinnon et al. 2016). Kamp Mound 7 may consist of either two sequentially constructed tomb complexes that were capped simultaneously or a primary tomb complex with an intrusive tomb and extended ramp that were later capped. Whether Mound 3 at Gast Farm represents similar construction activities is unclear. The most apparent element of the mound is an approximately $12 \mathrm{~m}$ diameter circle, perhaps the primary or initial mound construction (Mound 3A), represented by a positive magnetic anomaly. A diffuse, weakly magnetic anomaly is located at its center, 


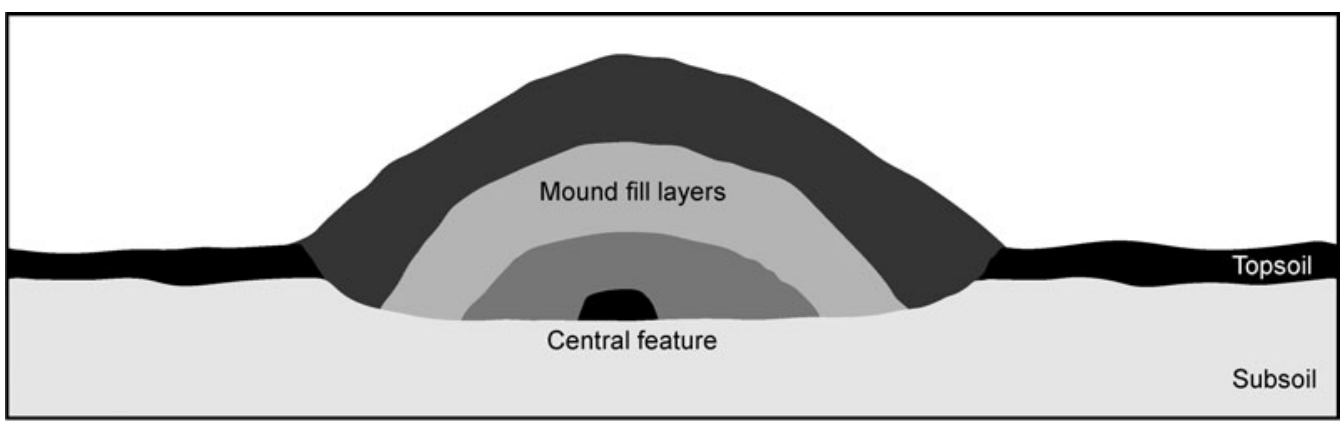

\section{Leveled mound}
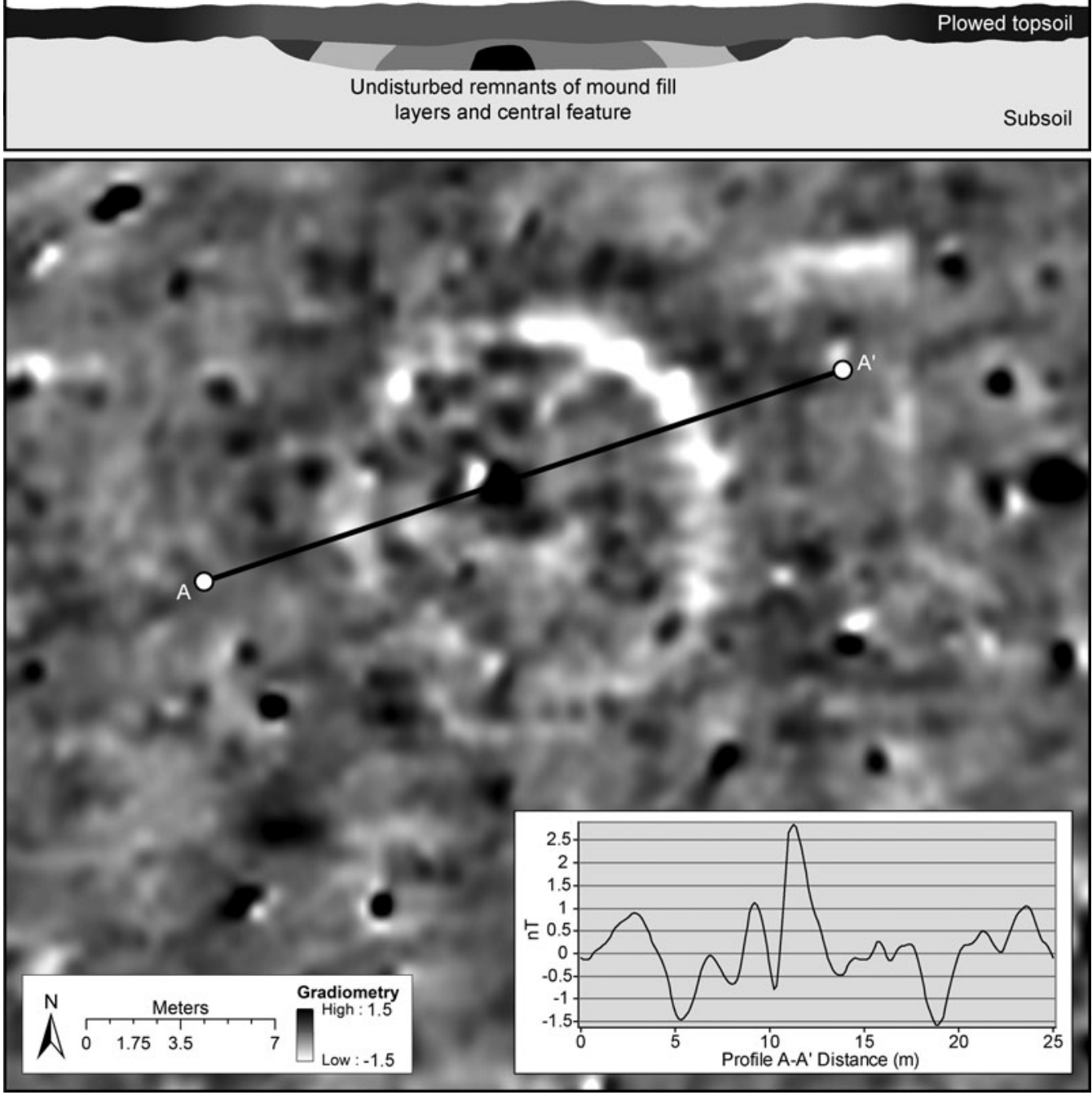

Figure 9. Top: conceptual profile of mound with subfloor burial chamber and alternating fill zones of high (dark) and low (light) magnetism. Middle: same mound plowed down, with burial chamber and traces of alternating high and low magnetic fill zones below the plow zone. Bottom: magnetic results of Mound 5 showing concentric high and low zones and central feature. 
and this likely indicates a tomb. The mound appears to have been rebuilt or elongated nearly $5 \mathrm{~m}$ to the east (Mound 3B), but no secondary or intrusive tomb is noticeable. It is possible that the order of rebuilding was the opposite, given that the Mound 3A anomalies appear to be superimposed upon 3B. Mound 6 exhibits a wide ring of positive magnetism surrounding an interior that consists mostly of negative magnetic soil with a pronounced high-magnetic feature slightly offset north of the mound's center.

Faint traces of other possible mounds exist, but these six are the most clearly evident from examination of the magnetic data. The central features, which we suspect are crypts with burials, could instead represent looters' pits that were backfilled with soil of higher magnetism. This is unlikely, however, because the fill of looters' pits would be more heterogeneous, with mixed topsoil and mound fill. Test units excavated elsewhere on the site during the 19911994 field schools serve as useful analogs. Backfilled with mixed soil, they are difficult or impossible to discern in the magnetic data.

The mound group locus coincides with the only portion of Gast Farm that has both a surface concentration of Early Woodland pottery and few Middle or Late Woodland ceramics. Early Woodland artifacts in the mound locus might have been included in fill obtained from nearby habitation deposits. Alternatively, Middle Woodland people may have deliberately built the mounds on an earlier occupation area, albeit one with a low density of pit features.

\section{Mound Height and Volume}

If the outermost edge of each mound's magnetic signature represents the approximate edge of the mound before it was leveled, then comparisons with documented mounds allow us to estimate each mound's original height and fill volume. Because much of the mound fill at Gast Farm consists of light-colored sediment (as shown by Mound 4 surface soil and as suggested by negative magnetism within the mounds), knowing the approximate volume of fill displaced from the mounds might help clarify the origin of the lightcolored bands thought to have been earthworks.

Several assumptions underlie the method we use to estimate mound height and volume: (1) the maximum diameter of each mound's magnetic signature approximates the mound's actual diameter, (2) the original form of each mound approximated a spherical cap (i.e., a dome), and (3) height-diameter relationships of nearby mounds can be used to estimate those relationships for the Gast Farm mounds. Assumption 1 is based on the observation that geophysical surveys of extant mounds show concordance between observed and magnetically surveyed mound edges (e.g., McKinnon et al. 2016), although we may underestimate mound diameters because final capping episodes probably extended mound boundaries beyond the edges of detectable sub-plow zone magnetic signatures. Assumption 2 recognizes that although many mounds have tapered rather than dome-like profiles, tapering is slight on minimally disturbed mounds (e.g., Charles et al. 1988; Herold 1971; Walker 1952). Assumption 3 notes that although nineteenth-century mound measurements are rarely as precise as one would like, if a clear relationship exists between height and diameter among undisturbed mounds locally, there is no reason to suspect the Gast Farm mounds would deviate from that pattern.

In the late nineteenth century, enthusiasts affiliated with the Davenport and Muscatine Academies of Science recorded hundreds of mounds in Iowa and Illinois. Their reports constitute the only records of numerous mounds later leveled by plowing. Davenport Academy members measured the diameters and heights of 24 mounds located within $3 \mathrm{~km}$ of Gast Farm, nearly all of which are no longer extant (Blumer 1883; Gass 1883). Diameters were measured to an accuracy of $5 \mathrm{ft}$. $(1.52 \mathrm{~m})$ and heights to an accuracy of $0.5 \mathrm{ft}$. $(0.15 \mathrm{~m})$ (Supplemental Table 2). Surface-area measurements would be preferable to heights in calculating volume, but they are not available for these leveled mounds. Figure 10 illustrates the relationship between reported mound diameters and heights. The resulting linear regression equation describes a positive correlation between the two measurements $\left(\mathrm{R}^{2}=\right.$ 0.8385 ), permitting prediction of height on the basis of diameter. We applied that equation to the leveled Gast Farm mounds and calculated their approximate original heights, which range from $1.3 \mathrm{~m}$ for Mound 2 to $1.8 \mathrm{~m}$ for Mound 4 


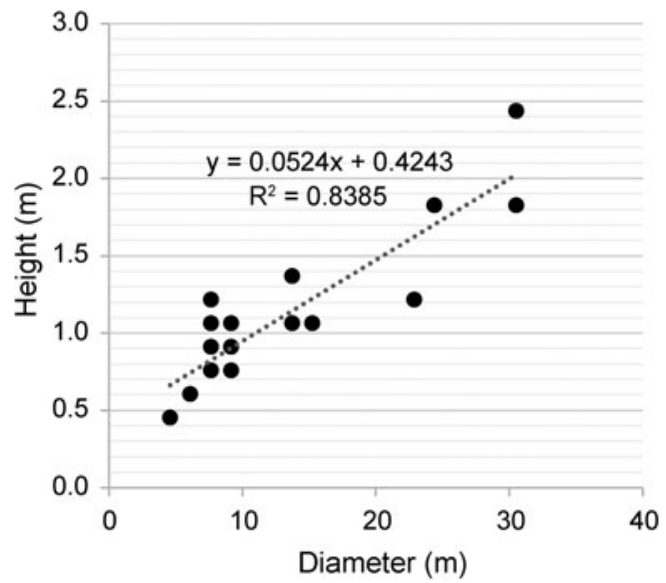

Figure 10. Dimensions of recorded mounds in the Gast Farm vicinity (see Supplemental Table 2) and linear regression of height-diameter relationship.

(Table 1). Height estimates are conservative because of our likely underestimation of mound diameters.

With diameter (and radius) and height estimates in hand, and employing our assumption that original mound shapes approximated domes, we calculated the amount of each mound's fill using the formula for the volume of a spherical cap:

$$
\text { Volume }=\left(\frac{1}{6}\right) \pi h\left(3 a^{2}+h^{2}\right)
$$

where $h$ is the height of the cap (i.e., mound height) and $a$ is the radius of the base of the cap (i.e., mound radius; Pamula 2020). Table 1 shows that the estimated fill volumes ranged from $128 \mathrm{~m}^{3}$ for Mound 2 to nearly $530 \mathrm{~m}^{3}$ for Mound 4. Volumes of Mounds 3A and 3B are

Table 1. Approximate Diameters and Inferred Heights and Volumes of Gast Farm Mounds.

\begin{tabular}{lcccc}
\hline $\begin{array}{l}\text { Mound } \\
\text { Number }\end{array}$ & $\begin{array}{c}\text { Diameter } \\
(\mathrm{m})\end{array}$ & $\begin{array}{c}\text { Radius } \\
(\mathrm{m})\end{array}$ & $\begin{array}{c}\text { Height } \\
(\mathrm{m})\end{array}$ & $\begin{array}{c}\text { Volume } \\
\left(\mathrm{m}^{3}\right)\end{array}$ \\
\hline 1 & 25 & 12.5 & 1.7 & 428.4 \\
2 & 16 & 8.0 & 1.3 & 128.0 \\
$3 \mathrm{~A}$ & 25 & 12.5 & 1.7 & 428.4 \\
3B & 25 & 12.5 & 1.7 & 428.4 \\
4 & 27 & 13.5 & 1.8 & 529.8 \\
5 & 22 & 11.0 & 1.6 & 301.8 \\
6 & 20 & 10.0 & 1.5 & 232.9 \\
Total & & & & $2,477.7$ \\
\hline
\end{tabular}

calculated separately even though the apparent rebuilding episode probably incorporated much of the existing mound. For that reason, and in view of the possibility that mound shapes were slightly tapered rather than strictly dome-like, we reduce the total fill volume of $2,477.7 \mathrm{~m}^{3}$ by around $10 \%$ to $2,200 \mathrm{~m}^{3}$, still a conservative estimate.

Redeposition of approximately $2,200 \mathrm{~m}^{3}$ of mound fill through leveling and plowing can account for the light-colored bands once thought to be remnants of earthworks. The cardinaldirection orientations of the approximately 25 $\mathrm{m}$ wide bands can be traced for at least $450 \mathrm{~m}$, so the area covered by the bands is no less than $11,250 \mathrm{~m}^{2}$. Spreading $2,200 \mathrm{~m}^{3}$ of fill over $11,250 \mathrm{~m}^{2}$ covers the filled area to a mean depth of $20 \mathrm{~cm}$. The light-colored bands, consequently, may owe their origin to mound fill that was moved east and south-which have always been the orientations of the planting rows-as the mounds and their immediate surroundings were leveled. Field-school excavation units near one of these bands in the eastern part of the site revealed an Ap (plow zone) horizon slightly lighter in color than the immediately underlying A1 horizon (Whelan et al. 2001), possibly reflecting addition of redeposited mound fill. The small mounds must have been leveled in the nineteenth or early twentieth century because longtime owner Dan Gast knew about only the single large mound he leveled in the $1950 \mathrm{~s}$.

\section{Discussion and Conclusion}

In their call for an "inquiry-based archaeogeophysics," Thompson and colleagues (2011) contended that "persistent places" (Schlanger 1992) are well suited to anthropological study using shallow geophysical methods. Changes and continuities in the forms of and relationships between dwellings, communities, and monuments are just some of the topics that geophysics can help address in places with long histories. Mound groups are persistent places in several senses. They were often built in stages over many years. They were often maintained and reused by descendant groups or newcomers. They generally retain their form for long spans 
of time. They continue to hold spiritual and religious significance for many Native Americans. And-as we see in the present study-certain of their features can remain intact even after the above-ground portion is removed. Gast Farm is doubly persistent: as one of the most prominent alluvial fans in its locality, it attracted settlement as soon as it formed in the early Holocene and ultimately supported numerous Archaic and Woodland communities (Bettis et al. 1992). Middle Woodland people who occupied the eastern part of the site on a periodic basis over approximately 200 years (Green 2018) modified the central fan surface by building at least six conical mounds and rebuilding or enlarging at least one of them.

Magnetic survey in the central part of Gast Farm addressed several research questions. We sought to determine whether the single previously reported mound retained any subsurface integrity (it does) and if structural features survive (they do). We asked if there was any subsurface signature of the apparent geometric earthworks (there is not). Consequently, we learned that leveled mounds are not necessarily destroyed and that features evident from aerial imagery require verification. The survey's finding that off-mound pit features appear to be sparse in the mound locus also supports the controlled surface collection results, which suggested that Middle and Late Woodland domestic activities and facilities remained apart from the Middle Woodland mortuary/ritual precinct.

A surprising result of the magnetic survey was that the site had not one but at least six mounds, demonstrating the method's effectiveness in identifying previously unknown mounds as well as verifying known mound loci. These mounds contain central features, probably crypts as in other Havana Hopewell mounds. The crypts at Gast Farm are small, comparable in size or smaller than the approximately $2 \times 3 \mathrm{~m}$ burial pits beneath the Albany mounds (11WT1) in northwestern Illinois (Herold 1971). In number and layout, the mound group resembles the Kingston site, a group of seven Havana Hopewell mounds on an alluvial fan $28 \mathrm{~km}$ south of Gast Farm (Scholtz 1960; Straffin 1971). The Kingston mounds have been plowed for decades and are good candidates for geophysical survey.
The Gast Farm mounds are comparable in diameter to Middle Woodland mounds throughout the region (Alex et al. 2019; Harrison 1886; Herold 1970, 1971; Lippincott and Herold 1965). Spacing of Havana Hopewell mound groups along the Mississippi River suggests territorial demarcation (Benn 1988), although little is known about contemporaneity or duration of site use.

Most Havana Hopewell primary mound interments are in crypts or other subfloor pits (Brown 1979). Such treatment insulates those burials from disturbance by simple land-leveling or plowing. Similarly, Middle Woodland Goodall and Norton tradition mounds in Indiana and Michigan feature burial pits that escape plowing (Kingsley 1999; Schurr 1999). Similar patterns occur among mounds throughout Minnesota (Arzigian and Stevenson 2003) and Wisconsin (Amy Rosebrough, personal communication 2020). We can therefore state with assurance that in the Prairie Peninsula and upper Great Lakes regions, mound leveling will not destroy all associated features at most Middle Woodland mounds. Subfloor burial features are likely to escape plowing and leveling in other areas too. Furthermore, our survey and earlier work (e.g., Mathys 1997; Schurr 1999) demonstrate that magnetic survey is an effective and efficient means of detecting leveled mounds and gaining information about mound diameter, fill variability, and pit feature location and size. Dimensional data for intact local mounds allow estimation of height and volume for leveled mounds. Here, these estimates helped us suggest the mound-fill origin of the surface discolorations we thought might be earthworks.

Large-area geophysical surveys now can be accomplished efficiently as motorized, multisensor arrays become mainstream (Kvamme 2017; Opitz and Herrmann 2018). Geophysical surveys can rapidly cover large tracts where mounds have been reported or suspected. Follow-up work using targeted geophysical assessment or testing can be accomplished as needed. Previously unknown mounds, mounds that had been considered destroyed, and mounds whose status was unknown can be revealed or rediscovered, improving knowledge of ancient landscapes and expanding preservation and conservation opportunities. 
Acknowledgments. We thank property owners Linda Gast and Jack Wilson as well as farm operator Bryan Hoben for permitting and assisting with fieldwork at Gast Farm. Fieldwork and analyses were supported by the National Geographic Society Committee for Research and Exploration (grant 9938-16) and a Keefer Senior Faculty Grant and developmental leave from Beloit College. Vergil Noble (Midwest Archeological Center, National Park Service) contributed support from the National Historic Landmarks Program and provided valuable input. Research was supported by the Spatial Archaeometry Research Collaborations program of the Center for Advanced Spatial Technologies, University of Arkansas (funded by National Science Foundation award \#1321443); thanks in particular to Adam Barnes and Rachel Opitz. Lew Somers of Geoscan Research USA advised on strategies for interpreting magnetic data. Thanks also to former Beloit College and University of Iowa students Alexandra Flores, Brianna Hoffmann, Julie Plummer, and Glenne Tietzer, and to Iowa OSA staffers John Doershuk, William Whittaker, Mary De La Garza, and Michael Perry. Thanks to Alondra Landa and Linda Forman for the Spanish language abstract and to Mark Schurr, David Benn, and the American Antiquity reviewers for helpful comments and suggestions.

Data Availability Statement. Project data are housed at the Office of the State Archaeologist, University of Iowa, Iowa City; the Midwest Archeological Center, National Park Service, Lincoln, Nebraska; and the Spatial Archaeometry Research Collaborations program, University of Arkansas, Fayetteville. See Supplemental Text 1 for access to data.

Supplemental Materials. For supplemental material accompanying this article, visit https://doi.org/10.1017/aaq.2020. 103.

Supplemental Text 1. Geospatial and Geophysical Data Processing and Access.

Supplemental Figure 1. Orthorectified low-altitude color infrared air photo of Gast Farm taken June 1972 (crops newly sprouted). Note light-colored leveled mound locus and dark-colored Middle Woodland and Late Woodland occupation loci. Light-colored bands in the center of the site were formerly considered possible earthworks. Bright area at east end of site is dredge spoil from adjacent slough. (Photo by Ferrel Anderson. Used with permission.)

Supplemental Figure 2. Top: Exaggerated vertical lidar image of Gast Farm with ArcScene enhancement. Bottom: Exaggerated oblique lidar image with ArcScene enhancement. (Images created by William Whittaker, Iowa OSA, and used with permission.)

Supplemental Table 1. Summary of Remote Sensing Datasets, Their Sources, and Feature Visibility.

Supplemental Table 2. Dimensions of Conical Mounds in the Gast Farm Vicinity Recorded by the Davenport Academy of Natural Sciences.

\section{References Cited}

Alex, Lynn M., William Green, and Robin M. Lillie 2019 Toolesboro: A Havana-Hopewell Mound Group in
Southeastern Iowa. Journal of the Iowa Archeological Society 66:1-79.

Arzigian, Constance A., and Katherine P. Stevenson

2003 Minnesota's Indian Mounds and Burial Sites: A Synthesis of Prehistoric and Early Historic Archaeological Data. Publication No. 1. Minnesota Office of the State Archaeologist, St. Paul.

Aspinall, Arnold, Chris Gaffney, and Armin Schmidt

2009 Magnetometry for Archaeologists. AltaMira Press, Lanham, Maryland.

Barnhart, Terry A.

2015 American Antiquities: Revisiting the Origins of American Archaeology. University of Nebraska Press, Lincoln.

Barrier, Casey, and Timothy J. Horsley

2014 Shifting Communities: Demographic Profiles of Early Village Population Growth and Decline in the Central American Bottom. American Antiquity 79:295-313.

Bartington Instruments

2020 Operation Manual for Grad601 Single Axis Magnetic Field Gradiometer System. Electronic document, http://www.bartington.com/grad601, accessed April $14,2020$.

Benn, David W.

1988 Archaeological Cultural Resources. In Archaeology and Geomorphology in Pools 17 \& 18, Upper Mississippi River, edited by David W. Benn, pp. 92-227. CAR-714. Center for Archaeological Research, Southwest Missouri State University, Springfield.

2009 Continuity in the Woodland Mound Building Tradition of Northeastern Iowa. Journal of the Iowa Archeological Society 56:1-32.

Benn, David W., and William Green

2000 Late Woodland Cultures in Iowa. In Late Woodland Societies: Tradition and Transformation across the Midcontinent, edited by Thomas E. Emerson, Dale L. McElrath, and Andrew C. Fortier, pp. 429-496. University of Nebraska Press, Lincoln.

Bennett, Rebecca, Dave Cowley, and Véronique De Laet

2014 The Data Explosion: Tackling the Taboo of Automatic Feature Recognition in Airborne Survey Data. Antiquity 88:896-905.

Bettis, E. Arthur, III, Richard G. Baker, William Green, Mary K. Whelan, and David W. Benn

1992 Late Wisconsinan and Holocene Alluvial Stratigraphy, Paleoecology, and Archaeological Geology of East-Central Iowa. Guidebook Series No. 12. Geological Survey Bureau, Iowa Department of Natural Resources, Iowa City.

Betts, Colin, and Marshall Stay

2017 Geophysical Investigation at the Ward Long Mound Site, Allamakee County, Iowa. Journal of the Iowa Archeological Society 64:45-51.

Bevan, Bruce W.

1983 Electromagnetics for Mapping Buried Earth Features. Journal of Field Archaeology 10:47-54.

Bigman, Daniel P., and Daniel M. Seinfeld

2017 The Anthropological Potential of GroundPenetrating Radar for Southeastern Earthen Mound Investigations: A Case Study from Letchworth Mounds, Tallahassee, Florida. In Archaeological Remote Sensing in North America: Innovative Techniques for Anthropological Applications, edited by Duncan P. McKinnon and Bryan S. Haley, pp. 185-197. University of Alabama Press, Tuscaloosa.

Blumer, A.

1883 Exploration of Mounds in Louisa County, Iowa. 
Proceedings of the Davenport Academy of Natural Sciences 3:132-133.

Britt, Tad, Michael Hargrave, and Janet Simms 2002 Geophysical Archeological Survey at Poverty Point State Historic Site (16WC5) West Carroll Parish, Louisiana. ERDC SR-02-13. Construction Engineering Research Laboratory, Engineer Research and Development Center, U.S. Army Corps of Engineers, Champaign, Illinois.

Brown, James A.

1979 Charnel Houses and Mortuary Crypts: Disposal of the Dead in the Middle Woodland Period. In Hopewell Archaeology: The Chillicothe Conference, edited by David S. Brose and N'omi Greber, pp. 211-219. Kent State University Press, Kent, Ohio.

Brown, Melvin D.

1988 Soil Survey of Louisa County, Iowa. Soil Conservation Service, U.S. Department of Agriculture, Washington, DC.

Buikstra, Jane E.

1988 The Mound-Builders of Eastern North America: A Regional Perspective. Stichting Nederlands Museum voor Anthropologie en Praehistorie, Amsterdam, Netherlands.

Burks, Jarrod, and Robert A. Cook

2011 Beyond Squier and Davis: Rediscovering Ohio's Earthworks Using Geophysical Remote Sensing. American Antiquity 76:667-689.

Burks, Jarrod, and Kellie Locke-Rogers

2015 Geophysical Survey Results from the Beloit College Mound Group (47Ro15), an Early Late Woodland Period Effigy Mound Group in Southern Wisconsin. OVAI Contract Report 2015-32. Ohio Valley Archaeology Inc., Columbus, Ohio.

Charles, Douglas K., Steven R. Leigh, and Jane E. Buikstra (editors)

1988 The Archaic and Woodland Cemeteries at the Elizabeth Site in the Lower Illinois Valley. Research Series Vol. 7. Center for American Archeology, Kampsville, Illinois.

Charles, Douglas K., Julieann Van Nest, and Jane E. Buikstra 2004 From the Earth: Minerals and Meaning in the Hopewellian World. In Soil, Stones, and Symbols: Cultural Perceptions of the Mineral World, edited by Nicole Boivin and Mary Ann Owoc, pp. 43-70. UCL Press, London.

Clark, Anthony

1990 Seeing beneath the Soil: Prospecting Methods in Archaeology. B. T. Batsford, London.

Dalan, Rinita A.

1991 Defining Archaeological Features with Electromagnetic Surveys at Cahokia Mounds State Historic Site. Geophysics 56:1280-1287.

2006 Magnetic Susceptibility. In Remote Sensing in Archaeology: An Explicitly North American Perspective, edited by Jay K. Johnson, pp. 161-203. University of Alabama Press, Tuscaloosa.

Davis, Dylan S., Matthew C. Sanger, and Carl P. Lipo

2019 Automated Mound Detection Using Lidar and Object-Based Image Analysis in Beaufort County, South Carolina. Southeastern Archaeology 38:23-37.

De Vore, Steven L.

2009 Geophysical Investigations at the Nezekaw Terrace Mound Group (Site 13AM82), Effigy Mounds National Monument, Allamakee County, Iowa. Technical Report No. 118. U.S. National Park Service, Midwest Archeological Center, Lincoln, Nebraska.

2014 Geophysical Investigations at Iowaville. Journal of the Iowa Archeological Society 61:23-28.
2015 Magnetic Investigations of the McKinney Site at the Toolesboro State Preserve in Louisa County, Iowa. Poster presented at the 73rd Annual Plains Anthropological Conference, Iowa City, Iowa.

Drass, Richard R., Susan C. Vehik, and Stephen M. Perkins 2019 Baffles and Stockades: Entryway Construction at Southern Plains Fortifications, A.D. 1500-1850. Journal of Field Archaeology 44:565-580.

Dunne, Michael T.

2002 Change and Continuity in Prehistoric Foodways: A Paleoethnobotanical Analysis of the Middle to Late Woodland Transition at the Gast Farm Site (13LA12) in Southeast Iowa. $\mathrm{PhD}$ dissertation, Department of Anthropology, University of Iowa, Iowa City.

Fairbanks, Charles H.

1956 Archeology of the Funeral Mound, Ocmulgee National Monument, Georgia. Archeological Research Series No. 3. National Park Service, Washington, DC.

Ford, James A., and Gordon R. Willey

1941 An Interpretation of the Prehistory of the Eastern United States. American Anthropologist 43:325-363.

Fowler, Melvin L.

1977 Aerial Archeology at Cahokia. In Aerial Remote Sensing Techniques in Archeology, edited by Thomas R. Lyons and Robert K. Hitchcock, pp. 65-80. Reports of the Chaco Center No. 2. National Park Service and University of New Mexico, Albuquerque.

Friberg, Christina M.

2018 Igniting Interaction through Mississippian TraditionMaking: An Interregional Analysis at the Audrey Site (11GE20). PhD dissertation, Department of Anthropology, University of California, Santa Barbara.

Gass, Jacob

1883 Exploration of Mounds in Louisa County, Iowa Proceedings of the Davenport Academy of Natural Sciences 3:140-146.

Giardino, Marco, and Bryan S. Haley

2006 Airborne Remote Sensing and Geospatial Analysis. In Remote Sensing in Archaeology: An Explicitly North American Perspective, edited by Jay K. Johnson, pp. 47-77. University of Alabama Press, Tuscaloosa.

Gibson, Jon L.

2019 Archaic Earthworks of the Lower Mississippi Valley: Interpretations from the Field. Louisiana State University Press, Baton Rouge.

Green, William

2018 High Resolution Mapping and Geophysical Assessment of the Gast Farm Site (13LA12), Southeast Iowa. Logan Museum of Anthropology, Beloit College. Submitted to the National Geographic Society, Washington, DC, and the Center for Advanced Spatial Technologies, University of Arkansas, Fayetteville.

Green, William, and Rebecca Wallace

1991 Woodland Community Definition at the Gast Farm Site (13LA12), Louisa County, Iowa. Paper presented at the 36th Annual Midwest Archaeological Conference, La Crosse, Wisconsin.

Haley, Brian S.

2014 The Big Picture at Hollywood: Geophysical and Archaeological Investigations at a Mississippian Mound Centre. Archaeological Prospection 21:39-47.

Hammerstedt, Scott W., Jami J. Lockhart, Patrick C. Livingood, Tim Mulvihill, Amanda L. Regnier, George Sabo III, and John R Samuelson

2017 Multisensor Remote Sending at Spiro: Discovering Intrasite Organization. In Archaeological Remote 
Sensing in North America: Innovative Techniques for Anthropological Applications, edited by Duncan P. McKinnon and Bryan S. Haley, pp. 11-27. University of Alabama Press, Tuscaloosa.

Hargrave, Michael L., Tad Britt, and Matthew D. Reynolds 2007 Magnetic Evidence of Ridge Construction and Use at Poverty Point. American Antiquity 72:757-770.

Harrison, Charles E.

1886 Report of Mound Exploration Near Pine Creek, Muscatine County, Iowa. Proceedings of the Davenport Academy of Natural Sciences 4:197-198.

Henry, Edward R., Carl R. Shields, and Tristram R. Kidder 2019 Mapping the Adena-Hopewell Landscape in the Middle Ohio Valley, USA: Multi-Scalar Approaches to LiDAR-Derived Imagery from Central Kentucky. Journal of Archaeological Method and Theory 26:1513-1555.

Herold, Elaine Bluhm

1970 Hopewell Burial Mound Builders. Palimpsest 51:497-529.

Herold, Elaine Bluhm (editor)

1971 The Indian Mounds at Albany, Illinois. Anthropological Papers No. 1. Davenport Museum, Davenport, Iowa.

Herrmann, Jason T., Jason L. King, and Jane E. Buikstra

2014 Mapping the Internal Structure of Hopewell Tumuli in the Lower Illinois River Valley through Archaeological Geophysics. Advances in Archaeological Practice 2:164-179.

Horsley, Timothy J.

2015 The Use of Geophysical Survey in Archaeology. In Emerging Trends in the Social and Behavioral Sciences: An Interdisciplinary, Searchable, and Linkable Resource, edited by Robert A. Scott and Stephen M. Kosslyn. DOI:10.1002/9781118900772.etrds0356, accessed February $28,2020$.

Horsley, Timothy J., Jodie O'Gorman, and Michael Conner

2015 Understanding Settlement Organization through Geophysical Survey at the Morton Village Site, IL. Poster presented at the 80th Annual Meeting of the Society for American Archaeology, San Francisco.

Horsley, Timothy J., Alice P. Wright, and Casey R. Barrier

2014 Prospecting for New Questions: Integrating Geophysics to Define Anthropological Research Objectives and Inform Excavation Strategies at Monumental Sites. Archaeological Prospection 21:75-86.

Illinois State Geological Survey

2020 Illinois Height Modernization (ILHMP): LiDAR Data. Electronic document, https://clearinghouse.isgs. illinois.edu/data/elevation/illinois-height-modernizationilhmp-lidar-data, accessed October 14, 2020.

Iowa Department of Natural Resources

2020 One Meter Hillshade of Iowa, Derived from LiDAR Data. Electronic document, https://geodata.iowa.gov/ dataset/one-meter-hillshade-iowa-derived-lidar-data, accessed October 14, 2020.

Johnson, Rebecca L.

2002 Change in Woodland Diet and Vessel Form at the Gast Farm Site in Southeast Iowa. PhD dissertation, Department of Anthropology, University of Iowa, Iowa City.

Kassabaum, Megan C., Edward R. Henry, Vincas P. Steponaitis, and John W. O'Hear

2014 Between Surface and Summit: The Process of Mound Construction at Feltus. Archaeological Prospection 21:27-37.

King, Jason L., Duncan P. McKinnon, Jason T. Herrmann, Jane E. Buikstra, and Taylor H. Thornton
2017 The Role of Geophysics in Evaluating Structural Variation in Middle Woodland Mounds in the Lower Illinois River Valley. In Archaeological Remote Sensing in North America: Innovative Techniques for Anthropological Applications, edited by Duncan P. McKinnon and Bryan S. Haley, pp. 171-184. University of Alabama Press, Tuscaloosa.

Kingsley, Robert G.

1999 The Middle Woodland Period in Southern Michigan. In Retrieving Michigan's Buried Past: The Archaeology of the Great Lakes State, edited by John R. Halsey, pp. 148-172. Bulletin 64. Cranbrook Institute of Science, Bloomfield Hills, Michigan.

Kvamme, Kenneth L.

2003 Geophysical Surveys as Landscape Archaeology. American Antiquity 68:435-457.

2006a Magnetometry: Nature's Gift to Archaeology. In Remote Sensing in Archaeology: An Explicitly North American Perspective, edited by Jay K. Johnson, pp. 205-233. University of Alabama Press, Tuscaloosa.

2006b Integrating Multidimensional Geophysical Data. Archaeological Prospection 13:57-72.

2006c Data Processing and Presentation. In Remote Sensing in Archaeology: An Explicitly North American Perspective, edited by Jay K. Johnson, pp. 235-250. University of Alabama Press, Tuscaloosa.

2007a Geophysical Mappings and Findings at Northern Plains Village Sites. In Plains Village Archaeology: Bison-Hunting Farmers in the Central and Northern Plains, edited by Stanley A. Ahler and Marvin Kay, pp. 210-221. University of Utah Press, Salt Lake City.

2007b Integrating Multiple Geophysical Datasets. In Remote Sensing in Archaeology, edited by James R. Wiseman and Farouk El-Baz, pp. 345-374. Springer, New York.

2008 Remote Sensing: Archaeological Reasoning through Physical Principles and Pattern Recognition. In Archaeological Concepts for the Study of the Cultural Past, edited by Alan P. Sullivan III, pp. 65-84. University of Utah Press, Salt Lake City.

Kvamme, Kenneth L.

2017 A Decade of Geophysics and Remote Sensing in North American Archaeology: Practices, Advances, and Trends. In Archaeological Remote Sensing in North America: Innovative Techniques for Anthropological Applications, edited by Duncan P. McKinnon and Bryan S. Haley, pp. 215-230. University of Alabama Press, Tuscaloosa.

Kvamme, Kenneth, Eileen Ernenwein, Michael Hargrave, Thomas Sever, Deborah Harmon, Fred Limp, Burgess Howell, Michele Koons, and Jason Tullis

2006 New Approaches to the Use and Integration of Multi-Sensor Remote Sensing for Historic Resource Identification and Evaluation. Center for Advanced Spatial Technologies, University of Arkansas. Contract No. DACA72-02-C-0035. Submitted to the Department of Defense Strategic Environmental Research and Development Program, Herndon, Virginia.

Kvamme, Kenneth L., Jay K. Johnson, and Bryan S. Haley

2006 Multiple Methods Surveys: Case Studies. In Remote Sensing in Archaeology: An Explicitly North American Perspective, edited by Jay K. Johnson, pp. 251-267. University of Alabama Press, Tuscaloosa.

De Laet, Véronique, Etienne Paulissen, and Marc Waelkens 2007 Methods for the Extraction of Archaeological Features from Very High-Resolution Ikonos-2 Remote Sensing Imagery, Hisar (Southwest Turkey). Journal of Archaeological Science 34:830-841. 
Lasaponara, Rosa, Giovanni Leucci, Nicola Masini, Raffaele Persico, and Giuseppe Scardozzi

2016 Towards an Operative Use of Remote Sensing for Exploring the Past Using Satellite Data: The Case Study of Hierapolis (Turkey). Remote Sensing of Environment 174:148-164.

Limp, W. Fredrick

1987 Archeological Site Destruction in Arkansas. Technical Papers No. 6. Arkansas Archeological Survey, Fayetteville.

Lippincott, Kerry A., and Elaine Bluhm Herold

1965 Archaeological Investigations along the Henderson Creek Drainage Project, Henderson County, Illinois. In Middle Woodland Sites in Illinois, edited by Elaine Bluhm Herold, pp. 95-128. Bulletin No. 5. Illinois Archaeological Survey, University of Illinois, Urbana.

Lynott, Mark

1997 Geophysical Surveys at Two Earthen Mound Sites, Wright-Patterson Air Force Base, Ohio. Midwest Archeological Center, National Park Service, Lincoln, Nebraska.

2015 Hopewell Ceremonial Landscapes of Ohio: More than Mounds and Geometric Earthworks. Oxbow, Oxford, United Kingdom.

Mallam, R. Clark

1976 The Mound Builders: An American Myth. Journal of the Iowa Archeological Society 23:145-175.

Mangold, William L., and Mark R. Schurr

2006 The Goodall Tradition: Recent Research and New Perspectives. In Recreating Hopewell, edited by Douglas K. Charles and Jane E. Buikstra, pp. 206-226. University Press of Florida, Gainesville.

Mathys, Antone

1997 A Geophysical Survey at the Turkey River Mound Group Site, Clayton County, Iowa, for the Iowa State Archaeology Office, State Burials Program, Iowa City, Iowa. Reports of Investigations No. 422. Institute for Minnesota Archaeology, Minneapolis.

McCullough, Robert G.

2018 Geophysical Survey of Nadine Mound Group (11HE69), Henderson County, Illinois. Illinois Archaeology 30:122-136.

McKinnon, Duncan P., and Bryan S. Haley

2017 Evaluating the Use of Community Space at Two Southeastern Mound Centers Using Magnetic Gradient and Surface Collection Data. In Archaeological Remote Sensing in North America: Innovative Techniques for Anthropological Applications, edited by Duncan P. McKinnon and Bryan S. Haley, pp. 46-64. University of Alabama Press, Tuscaloosa.

McKinnon, Duncan P., and Bryan S. Haley (editors)

2017 Archaeological Remote Sensing in North America: Innovative Techniques for Anthropological Applications. University of Alabama Press, Tuscaloosa.

McKinnon, Duncan P., Jason L. King, Jane E. Buikstra, Taylor H. Thornton, and Jason T. Herrmann

2016 Returning to Kamp Mound Group (11C12): Results from Geomagnetic Survey and High-Density Topographic Mapping in Calhoun County, Illinois. Midcontinental Journal of Archaeology 41:231-254.

Messerole, Megan Stroh

2017 What's Below the Surface: Geophysical Investigations of the Webb Mounds (13OB28), O'Brien County, Iowa. Journal of the Iowa Archeological Society 64:52-60.

Milner, George R.

2004 The Moundbuilders: Ancient Peoples of Eastern North America. Thames and Hudson, New York.
2009 Ancient Earthen Architecture in the Midwest. In Archaeology in America: An Encyclopedia, Vol. 2, edited by Francis P. McManamon, pp. 39-42. Greenwood Press, Westport, Connecticut.

Neverett, Margot $\mathrm{S}$.

2001 A Zooarchaeological Analysis of the Middle to Late Woodland Transition at the Gast Farm Site (13LA12) in Southeastern Iowa. PhD dissertation, Department of Anthropology, University of Iowa, Iowa City.

Newhall, John B.

1841 Sketches of Iowa, or the Emigrant's Guide. J. H. Colton, New York.

Opitz, Rachel, and Jason Herrmann

2018 Recent Trends and Long-Standing Problems in Archaeological Remote Sensing. Journal of Computer Applications in Archaeology 1:19-41.

Pamula, Hannah

2020 Spherical Cap Volume Calculation. Electronic document, https://www.omnicalculator.com/math/spherevolume\#spherical-cap-volume-calculation, accessed January 29, 2020.

Panagiotakis, Costas, Eleni Kokinou, and Apostolos Sarris

2011 Curvilinear Structure Enhancement and Detection in Geophysical Images. IEEE Transactions on Geoscience and Remote Sensing 49:2040-2048.

Pasolli, Edoardo, Farid Melgani, and Massimo Donelli

2009 Automatic Analysis of GPR Images: A PatternRecognition Approach. IEEE Transactions on Geoscience and Remote Sensing 47:2206-2217.

Petersen, Robert W.

1984 A Survey of the Destruction of Effigy Mounds in Wisconsin and Iowa-A Perspective. Wisconsin Archeologist 65(1):1-31.

Quimby, George I., Jr.

1941 The Goodall Focus: An Analysis of Ten Hopewellian Components in Michigan and Indiana. Prehistory Research Series Vol. 2, No. 2. Indiana Historical Society, Indianapolis.

Riley, Melanie A., and Joseph A. Tiffany

2014 Using LiDAR Data to Locate a Middle Woodland Enclosure and Associated Mounds, Louisa County, Iowa. Journal of Archaeological Science 52:143-152.

Rosebrough, Amy L.

2011 Native American Mounds as Burial Mounds and Markers. Technical Memo 11-0001. State Archaeology and Maritime Preservation Program, Wisconsin Historical Society, Madison.

Rowe, Chandler W.

1958 A Crematorium at Aztalan. Wisconsin Archeologist 39(1):101-110.

Royster, Tom

ca. 1970 Camp Site on Gast Farm. Sketch map on file, Office of the State Archaeologist, University of Iowa, Iowa City.

Schlanger, Sarah $\mathrm{H}$

1992 Recognizing Persistent Places in Anasazi Settlement Systems. In Space, Time, and Archaeological Landscapes, edited by Jacqueline Rossignol and LuAnn Wandschneider, pp. 91-112. Plenum Press, New York.

Schneider, Anna, Melanie Takla, Alexander Nicolary, Alexandra Raab, and Thomas Raab

2015 A Template-Matching Approach Combining Morphometric Variables for Automated Mapping of Charcoal Kiln Sites. Archaeological Prospection 22:45-62.

Scholtz, James A.

1960 The Kingston Site: A Hopewell Mound Group in 
Southeastern Iowa. Journal of the Iowa Archeological Society 10:20-35.

Schurr, Mark R.

1999 Geophysical Surveys of Middle Woodland Mounds in Northwestern Indiana. Report of Investigations 99-1. Department of Anthropology, University of Notre Dame, Notre Dame, Indiana.

Silverberg, Robert

1968 Mound Builders of Ancient America: The Archaeology of a Myth. New York Graphic Society, Greenwich, Connecticut.

Skousen, B. Jacob

2019 Magnetometry Survey at the Otter Pond Site. Illinois Antiquity 54(1):1-5.

Snead, James E.

2018 Relic Hunters: Archaeology and the Public in Nineteenth-Century America. Oxford University Press, New York.

Straffin, Dean

1971 Wolfe Havana Hopewell Site. In Prehistoric Investigations, edited by Marshall McKusick, pp. 53-65. Report No. 3. Office of the State Archaeologist, University of Iowa, Iowa City.

Thompson, Victor D., Philip J. Arnold III, Thomas J. Pluckhahn, and Amber M. VanDerwarker

2011 Situating Remote Sensing in Anthropological Archaeology. Archaeological Prospection 18:195-213.

Timmerman, Nicholas A.

2020 Contested Indigenous Landscapes: Indian Mounds and the Political Creation of the Mythical "Mound Builder" Race. Ethnohistory 67:75-95.

Trier, Øivind Due, David C. Cowley, and Anders Ueland Waldeland

2019 Using Deep Neural Networks on Airborne Laser Scanning Data: Results from a Case Study of SemiAutomatic Mapping of Archaeological Topography on Arran, Scotland. Archaeological Prospection 26:165175.

Trier, Øivind Due, Siri Øyen Larsen, and Rune Solberg 2009 Automatic Detection of Circular Structures in High-Resolution Satellite Images of Agricultural Land. Archaeological Prospection 16:1-15.

Trier, Øivind Due, and Lars Holger Pilø

2012 Automatic Detection of Pit Structures in Airborne Laser Scanning Data. Archaeological Prospection 19:103-121.

Trier, Øivind Due, Maciel Zortea, and Christer Tonning

2015 Automatic Detection of Mound Structures in Airborne Laser Scanning Data. Journal of Archaeological Science: Reports 2:69-79.

U.S. Geological Survey

2020 Army Map Service, Photo A000700080454. Electronic document, earthexplorer.usgs.gov, accessed October 14, 2020.

Van Nest, Julieann

2006 Rediscovering the Earth: Some Ethnogeological Aspects of Illinois Valley Hopewell Mounds. In Recreating Hopewell, edited by Douglas K. Charles and Jane E. Buikstra, pp. 402-426. University Press of Florida, Gainesville.

Van Nest, Julieann, Douglas K. Charles, Jane E. Buikstra, and David L. Asch

2001 Sod Blocks in Illinois Hopewell Mounds. American Antiquity 66:633-650.

Verdonck, Lieven

2016 Detection of Buried Roman Wall Remains in
Ground-Penetrating Radar Data Using Template Matching. Archaeological Prospection 23:257-272.

Verhagen, Philip, and Lucian Drăguț

2012 Object-Based Landform Delineation and Classification from DEMs for Archaeological Predictive Mapping. Journal of Archaeological Science 39:698-703.

Walker, Winslow $\mathrm{M}$.

1952 The Dickison Mound Group, Peoria County, Illinois. In Hopewellian Communities in Illinois, edited by Thorne Deuel, pp. 12-41. Scientific Papers Vol. 5. Illinois State Museum, Springfield.

Weitzel, Timothy S., and William Green

1994 Weaver Ceramics from the Gast Farm Site (13LA12), Southeastern Iowa. Journal of the Iowa Archeological Society 41:130-139.

Whelan, Mary K., Michael Dunne, Rebecca Johnson, Blane Nansel, and Margot Neverett-Fulcher

2001 The Gast Farm Site (13LA12): The Havana Community. Manuscript on file, Office of the State Archaeologist, University of Iowa, Iowa City.

Whittaker, William E.

2020 Survivorship of Earthworks Mapped by T. H. Lewis in Iowa 1884-1894. Midcontinental Journal of Archaeology 45:16-38.

Whittaker, William E., and William Green

2010 Early and Middle Woodland Earthwork Enclosures in Iowa. North American Archaeologist 31:27-57.

Whittaker, William E., and Melanie A. Riley

2012 Human Landscapes in Iowa's Past: Establishing Mapping Protocols for LiDAR Identification and Mapping of Prehistoric Cultural Mounds. Contract Completion Report 1914. Office of the State Archaeologist, University of Iowa, Iowa City.

Whittaker, William E., and Glenn R. Storey

2008 Ground-Penetrating Radar Survey of the Sny Magill Mound Group, Effigy Mounds National Monument, Iowa. Geoarchaeology 23:474-499.

Wiewel, Adam S., and Steven L. De Vore

2018 Magnetic Gradiometry Survey Results at Gast Farm (13LA12), a Multicomponent Woodland Site in Louisa County, Iowa. Midwest Archeological Center, National Park Service, Lincoln, Nebraska. Submitted to the Logan Museum of Anthropology, Beloit College.

Willey, Gordon R.

1966 An Introduction to American Archaeology, Vol. 1. Prentice-Hall, Englewood Cliffs, New Jersey.

Wilson, Jeremy J., and Matthew D. Pike

2015 Warfare and Community Organization at Lawrenz Gun Club: A Case Study in the Advancement of Mississippian Archaeology through Geophysics. Illinois Antiquity 50(3):29-31.

Wright, Alice P.

2014 History, Monumentality, and Interaction in the Appalachian Summit Middle Woodland. American Antiquity 79:277-294.

Zimmer-Dauphinee, James

2017 Exploring the Deepest Reaches of Arkansas's Tallest Mounds with Electrical Resistivity Tomography. In $\mathrm{Ar}$ chaeological Remote Sensing in North America: Innovative Techniques for Anthropological Applications, edited by Duncan P. McKinnon and Bryan S. Haley, pp. 198 212. University of Alabama Press, Tuscaloosa.

Submitted May 4, 2020; Revised August 13, 2020; Accepted August 19, 2020 